\title{
Single cells and microcolonies of freshwater picocyanobacteria: a common ecology
}

\author{
Cristiana CALLIERI \\ C.N.R. - Istituto per lo Studio degli Ecosistemi, Largo V. Tonolli 50, 28922 Verbania Pallanza, Italy \\ *e-mail: c.callieri@ise.cnr.it
}

\begin{abstract}
Picocyanobacteria (Pcy) single-cells and microcolonies are common in lakes throughout the world, and abundant across a wide spectrum of trophic conditions. The single-celled Pcy populations tend to be predominant in large, deep oligo-mesotrophic lakes, while the microcolonies find optimal conditions in warmer, shallower and more nutrient rich lakes. Microcolonies of different size (from 5 to 50 cells) constitute a gradient without a net separation from single-celled types. Considering microcolonies as transitional forms from single-cells to colonial morphotypes it is conceivable to propose a common ecology where local communities are not isolated but linked by dispersal of multiple, potentially interactive, species. In this review abiotic forcing and biotic regulation of Pcy community structure and dynamics are examined to offer an updated view of Pcy ecology.
\end{abstract}

Key words: picocyanobacteria, freshwaters, Synechococcus, microcolonies, single-cells

\section{INTRODUCTION}

A phylogenomic study of the evolution of cyanobacterial traits shows that the earliest lineages were probably unicellular cells in terrestrial and/or freshwater environments (Sánchez-Baracaldo et al. 2005; Blank \& Sánchez-Baracaldo 2010) rather than in the marine habitat as suggested by Honda et al. (1999). This discovery opens new prospects for the study of freshwater picocyanobacteria (Pcy) and provides impetus and relevance for future phylogenetic and ecological investigations to clarify many uncertainties in the literature.

One of the most striking differences between freshwater and marine Pcy lies in the extraordinary richness of morphotypes and the unresolved phylogeny of Pcy in lakes. However, despite marked phylogenetic differences, Pcy have a similar pattern in their absolute and relative importance in freshwater and marine systems along the trophic gradient (Bell \& Kalff 2001).

Although studies of the ecology of microcolonies and colonial forms are few, there have been sufficient studies within the past $25 \mathrm{y}$ of Pcy in lakes and their role in food webs to warrant synthesis and further review (Stockner et al. 2000; Callieri 2008).

The picocyanobacteria exhibit two common morphologies: single cells, (coccoid, rods) and microcolonies. Under favorable environmental conditions some Pcy can develop mucilage or a sheath and remain near to the mother cell forming a clump. Here Pcy is designated as the single cells $(0.2-2.0 \mu \mathrm{m})$ which are the major component of the picophytoplankton community. Microcolonies of different size (from 5 to 50 cells) constitute a gradient without a clear separation from the single-celled type and should be considered Pcy.
The introduction of molecular biology and of singlecell analysis to microbial ecology has revolutionized our knowledge of taxonomy, dynamics and ecology of these organisms. The emergence of Pcy as an important research topic for limnologists and oceanographers provides an opportunity to discuss to what extent this large and diverse group of cyanobacteria shares a common ecology. The current challenge is to better understand the relationship between the diversity and ecology of Pcy and microcolonies and their interaction with the environmental factors that allow the proliferation of the most competitive genotypes. The study of genome divergence, lateral gene transfer and genomic islands will provide new opportunities for a better understanding of niche adaptation (Dufresne et al. 2008; Scanlan et al. 2009).

\section{TAXONOMY AND PHYLOGENETIC DIVERSITY}

Even more than for most prokaryotes (Komárek et al. 2004), the morphological features of Pcy are insufficiently distinct to provide a reliable basis for discriminating taxa. The criteria used for the definition of genera of single-celled Pcy e.g., Cyanobium, Synechococcus and Cyanothece dianae/cedrorum-type (Komárek 1996) have been supplanted by molecular methods which focus on clade divergence in the phylogenetic tree rather than on morphological differences. The clade containing Pcy (Synechococcus/Prochlorococcus/Cyanobium sensu Sánchez-Baracaldo et al. 2005 ) is formed by coccoid and rod-shaped cells with a diameter $<3 \mu \mathrm{m}$. Analysis of $16 \mathrm{~S}$ ribosomal DNA (rDNA) of freshwater Synechococcus shows it is polyphyletic genus and cannot be considered a natural taxon (Urbach et al. 1998; Robertson et al. 2001). In the phy- 


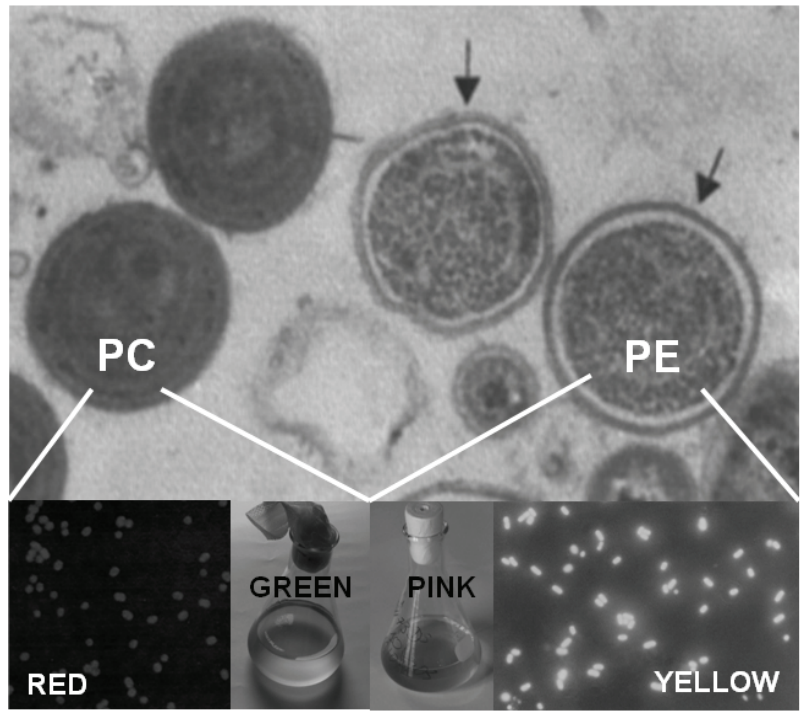

Fig. 1. Three different views of Pcy: liquid cultures (green: PC-cells, pink: PE-cells), epifluorescence photographs (under blue excitation: red cells: PC-cells, yellow cells: PE-cells), transmission electron microscope photo (showing the different internal structure of PC- and PE-cells).

logenetic tree the Antarctic strains represent a unique and highly adapted clade related only peripherally to Synechococcus sp. Cluster 5.2 (Marine Cluster B) (Vincent et al. 2000; Powell et al. 2005).

Over a decade has passed since the acknowledgement of the necessity that phenotypic diversity should be evaluated in conjunction with genotypic analysis in order to resolve whether a similar morphology also reflects a phylogenetic relationship. Even though many genetically distinct Synechococcus strains have been found (Robertson et al. 2001), it is still helpful to broadly classify Pcy into the two cell-types: the first with yellow autofluorescing phycoerythrin (PE-rich cells), and the second with red autofluorescing phycocyanin (PC-rich cells) as the major lightharvesting pigment (Wood et al. 1985; Ernst 1991) (Fig 1). Phycoerythrin-rich strains have an absorption peak at $\sim 560 \mathrm{~nm}$, and hence absorb green light effectively. Phycocyanin-rich strains have an absorption peak at $\sim 625 \mathrm{~nm}$, and absorb orange-red light effectively (Callieri et al. 1996; Haverkamp et al. 2008).

Phylogenetic studies are basically performed using sequence data derived from 16S rDNA which is a conserved gene but shows high pair-wise similarity in freshwater Pcy (Crosbie et al. 2003a) and cannot resolve the actual genetic variation that accompanies their physiological diversity (Urbach et al. 1998). Less conserved genetic markers can offer a more detailed definition of the diversity of Pcy (Haverkamp et al. 2009). In particular the spacer between the $16 \mathrm{~S}$ and $23 \mathrm{~S}$ rDNA (ITS-1) exhibits a great deal of length and sequence variation and can be used to differentiate marine and freshwater Pcy ecotypes using fingerprinting techniques (T-RFLP, DGGE or ARISA) (Rocap et al. 2002; Becker et al. 2002; Ernst et al. 2003). The study of functional genes as, for example, those encoding for phycocyanin and phycoerythrin $(c p c B A$ and $c p e B A)$ can offer another perspective on the evolution of Pcy, grouping the strains on the basis of pigment composition (Haverkamp et al. 2008). Indeed, it has been found that phylogenies based on phycobiliprotein rod gene components are not congruent with the 16S rRNA phylogeny whilst those based on the allophycocyanin core are congruent (Six et al. 2007; Haverkamp et al. 2009).

The phylogenetic approach combined with quantitative real-time PCR has been successfully used to assess Pcy community structure both in oceans (e.g., Ahlgren et al. 2006) and freshwaters (e.g., Becker et al. 2000, 2007). Using small subunit (ssu) rDNA sequences from novel culture isolates together with environmental samples from the Baltic Sea and seven freshwater lakes, Sánchez-Baracaldo et al. (2008) showed that freshwater Pcy communities encompass much greater diversity than is found in marine systems. They hypothesised a more rapid speciation in lakes allowed by geographical barriers and noticed that most of the Baltic Sea-derived sequences were closely related to freshwater lineages.

To provide a more realistic phylogenetic tree of cyanobacteria Sánchez-Baracaldo et al. (2005) used a combination of different molecular sequence data instead of individual genes. Flanking a selection of morphological traits into the backbone cyanobacterial tree they showed that the ancestral cyanobacterium was a single cell and that filamentous/colonial forms appeared later in time. The presence of a well-defined sheath, associated with the colonial lifestyle, is a trait which has been lost and attained several times during evolution. In Arctic lakes the Pcy isolated strains appeared to be closely related to Microcystis elabens (Vincent et al. 2000) now reclassified as a species of Aphanothece (Komárek \& Anagnostidis 1999). Thus, it is tempting to suggest that microcolonies, which are 
frequently found in freshwater, may be considered transitional forms from single-cells to true colonial. In this sense the investigations done by Crosbie et al. (2003a) confirm the existence of single-cell/single-colony strains, with different degrees of aggregation, possibly belonging to the group $\mathrm{H}$ and group B sub-alpine cluster I.

\section{SINGLE-CELLS VS MICROCOLONIES}

In the last ten years a growing interest in Pcy microcolony presence in lakes of different trophic state has been rekindled (Crosbie et al. 2003c; Callieri 2008). The abundance of microcolonies found under nutrient depleted conditions in mid-summer in temperate lakes suggests that colony formation may be a strategy for more efficient nutrient recycling, providing a self-sustaining microcosm that offers a competitive advantage over the free-living condition. This hypothesis has been considered unlikely for Pcy (Crosbie et al. 2003c), in the light of results obtained with the colony-forming marine alga Phaeocystis sp., where the formation of a diffusive boundary layer can strongly limit nutrient diffusion into the colonies (Ploug et al. 1999). At low phosphorus concentrations the colonial forms actually grow slower than the single-cell forms (Veldhuis \& Admiraal 1987), due to the lower cell-specific nutrient fluxes in colonies (Ploug et al. 1999). But in microcolonies, formed by 5-10 cells in one plane, the duplication should not be depressed as much as in a large, thick colony, where the diffusion of nutrients is impeded. In this case, exudates adsorbed to the cell surface can act as rich metabolite pools. Therefore, during the initial stage of its formation a microcolony can have a selective advantage in nutrient depleted waters.

Crosbie et al. (2003c) observed an increase of microcolonies in nutrient-poor surface waters in Lake Mondsee and attributed their formation to the production of photosynthate-rich mucilage in Pcy single-cells, that were actively photosynthesising organic carbon. As the leakage or excretion of photosynthate has been considered one protection mechanism against photochemical damage (Wood \& van Valen 1990), it is likely to also consider the effect of irradiance, at near-surface depths, as a stressor promoting clumping of daughter cells during duplication. Among the exudates produced by cyanobacteria the siderophores, iron-chelating compounds, are of great importance (Murphy et al. 1976). It has been hypothesized that siderophore production can provide a competitive advantage to cyanobacteria over other algae during iron stress, and can alter the bioavailabity of iron to the aquatic community (Wilhelm 1995). Nevertheless in diluted environments (open oceans) the loss of siderophores is highly probable and the cost of production not justified (Hopkinson \& Morel 2009). Particles are therefore considered the hotspots for siderophore production, mainly by heterotrophic bacteria (Hopkinson \& Morel 2009).

To better understand genus-specific microcolony formation one must consider the factors influencing cell aggregation, despite the many differences between microcolonies and aggregates. The results by Kobližek et al. (2000) suggest that, in culture at least, Synechococcus elongatus aggregates rapidly if exposed to blue light (30 minutes, $1000 \mu \mathrm{mol} \mathrm{m}^{-2} \mathrm{~s}^{-1}$ ) due to the effect of electron transfer downstream of PSI, with reactive oxygen radicals (ROS), likely triggering the aggregation. The production of glutathione, which is an important antioxidant of superoxide radicals, may be the metabolite inducing aggregation at high irradiance (Kobližek et al. 2000). PSI may therefore have an important role to play in the first stages of microcolony formation in lakes, but this hypothesis requires further study.

As well as cell metabolism alterations caused by external factors such as light, other important structural changes of Pcy single-cells must be mentioned as a causative factor inducing microcolony formation. Aggregation is an ATP-independent process without any de novo protein synthesis (Kobližek et al. 2000), and this indicates that some structures responsible for the aggregation must be present on the cell surface before irradiation. For example, in selected strains with different genotypes isolated from Lake Constance; Ernst et al. (1996) found that they possess a surface S-layer composed of regularly ordered globular protein layers that would facilitate colony formation. Also, in grazing (by Ochromonas sp.) induced microcolonies of PC-rich Cyanobium sp., rigid tubes from $100 \mathrm{~nm}$ to $1 \mu \mathrm{m}$ long (spinae) have been observed on the cell surface (Jezberová \& Komárková 2007). To what extent the formation of microcolonies is due to the presence of specific Synechococcus genotypes or is the result of a specific survival strategy is presently not fully understood (Ernst et al. 1999; Passoni \& Callieri 2000).

A fascinating hypothesis on microcolony formation is related to the observation by Postius \& Böger (1998) that exo-polysaccharides, exudated by Pcy, stimulate nitrogen fixation constituting microzones for diazotrophic bacteria growth. This finding opens new perspectives for the study of consortial, synergistic interactions that may be of critical importance to our understanding of colony formation in Pcy. Also, inside large microcolonies anoxic microsites can form and enable nitrogenase functioning. The negative relationship between the concentrations of available nitrogen forms $\left(\mathrm{NH}_{4}-\mathrm{N}\right.$, $\mathrm{NO}_{3}-\mathrm{N}$, urea-N) and large microcolonies in Lake Balaton (Mózes et al. 2006) induce to think over the role of nitrogen limitation on microcolonies increase in summer.

\section{SINGLE-CELL AND MICROCOLONY DYNAMICS}

\subsection{Seasonal dynamics}

Sufficient information is now available to delineate the different patterns of Pcy, single-cells and microcolonies, in lakes of different morphology, thermal regime and trophic state (Callieri 2008). In lakes of temperate regions maxima generally conform to a typical bimodal pattern, with a spring or early summer peak 


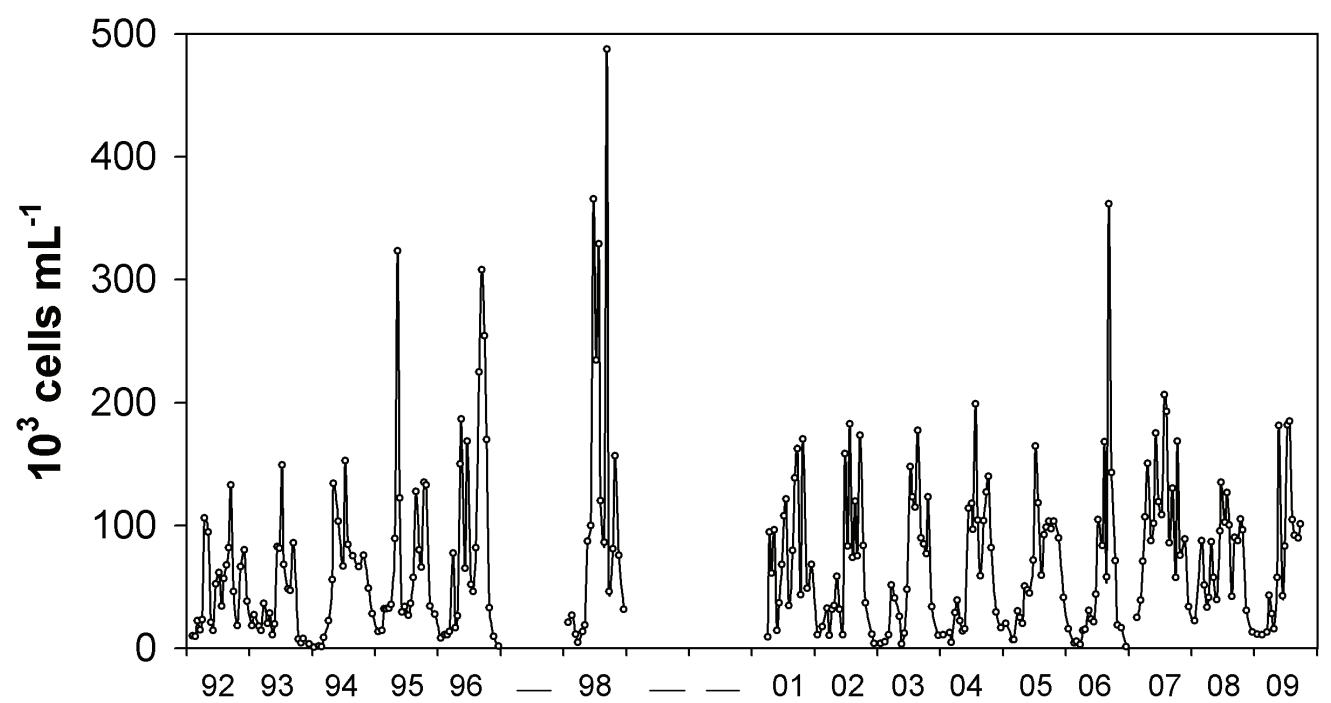

Fig. 2. Long-term Pcy abundance dynamics in Lake Maggiore, Northern Italy.

and a second peak during summer-autumn (Stockner $e t$ al. 2000). This is the case of most of the subalpine large lakes (e.g., Lake Maggiore, Lake Constance) without ice-cover, but also of Lake Stechlin, a deep oligo-mesotrophic lake in the Baltic Lake District where ice-cover occurs (Padisák et al. 2003). Nevertheless looking at the long-term series of Pcy abundance in Lake Maggiore (Fig. 2) (Callieri \& Piscia 2002), Lake Costance (Gaedke \& Weisse 1998), and Lake Stechlin (Padisák et al. 2003) not all the years are clearly bimodal. The interannual variability of Pcy dynamics is mainly related to differences in weather conditions which cause different spring mixing regimes and timing of water column stabilization (Weisse 1993). Studies in British Columbia's temperate oligotrophic lakes have shown a clear trend in both magnitude and timing of Pcy seasonal maxima related to levels of seasonal nutrient supplementation (Stockner \& Shortreed 1994).

Large spring peaks are also common in eutrophic, hypereutrophic and dystrophic shallow lakes (SimeNgando 1995; Jasser 1997; Mózes et al. 2006). The seasonal patterns found in Danish lakes (Søndergaard 1991), Canadian lakes (Pick \& Agbeti 1991), Lake Biwa, Japan (Maeda et al. 1992), English lakes (Hawley \& Whitton 1991; Sánchez-Baracaldo et al. 2008), Lake Mondsee, Austria (Crosbie et al. 2003c), lakes Bourget and Geneva, France (Personnic et al. 2009a) all lack the spring peak, there being only a summer or autumnal maximum. The lack of Pcy spring peak in these lakes was likely due to weak stratification in March-April and to relatively deep vertical mixing. This interpretation is further strengthened by recent studies of Lake Baikal, where owing to winter ice-cover and extended spring isothermal conditions, Pcy can reach high abundance only in summer months and lack a spring peak (Belykh et al. 2006).
In Arctic and Antarctic lakes Pcy are widely distributed, despite the fact they are generally present in low abundance the marine polar environment (Vincent 2000). In continental Antarctica in meromictic saline Ace Lake Pcy reached concentrations of one order of magnitude higher than in temperate lakes in summer - 8 $\times 10^{6}$ cells $\mathrm{mL}^{-1}$ (Vincent 2000). In the Antarctic Peninsula in Lake Boeckella (Izaguirre et al. 2003) Pcy abundance were as high as $3.6 \times 10^{5}$ cells $\mathrm{mL}^{-1}$ and represented up to $80 \%$ of phytoplankton biomass (Allende \& Izaguirre 2003). Nevertheless very low Pcy concentrations $\left(10^{2}-10^{3}\right.$ cells $\left.\mathrm{mL}^{-1}\right)$ were recorded in a set of shallow lakes and ponds in the Byers peninsula of maritime Antarctica (Toro et al. 2007).

Tropical lakes behave differently and show high cell numbers $\left(10^{5}-10^{6}\right.$ cell $\left.\mathrm{mL}^{-1}\right)$ throughout the season with higher early-spring peaks (Peštová et al. 2008) or summer peaks (Malinsky-Rushansky et al. 1995), depending upon the interactions of Pcy with other phytoplankton.

In Lake Maggiore the pronounced late summer peak of Pcy is composed by different morphotypes, including microcolonies (Passoni \& Callieri 2000) (Fig. 3a). Microcolonies are generally present throughout the euphotic zone, albeit in low abundance in all oligotrophic lakes e.g. representing only $25 \%$ of the single-cell forms in Lake Maggiore (Passoni \& Callieri 2000). The peak of the colonial coccoid cyanobacteria showed a seasonal distribution pattern similar to that of the microcolonies with maximum values in September-October (Fig. 3b). Aphanothece spp. has been recognised to dominate the natural population of colonial coccoid cyanobacteria in late summer-autumn, whereas the spring peak observed in 1996 was due to the presence of Microcystis sp. (Fig. 3b).

The peak abundance of Pcy microcolonies appears in summer or autumn in a variety of freshwater systems 

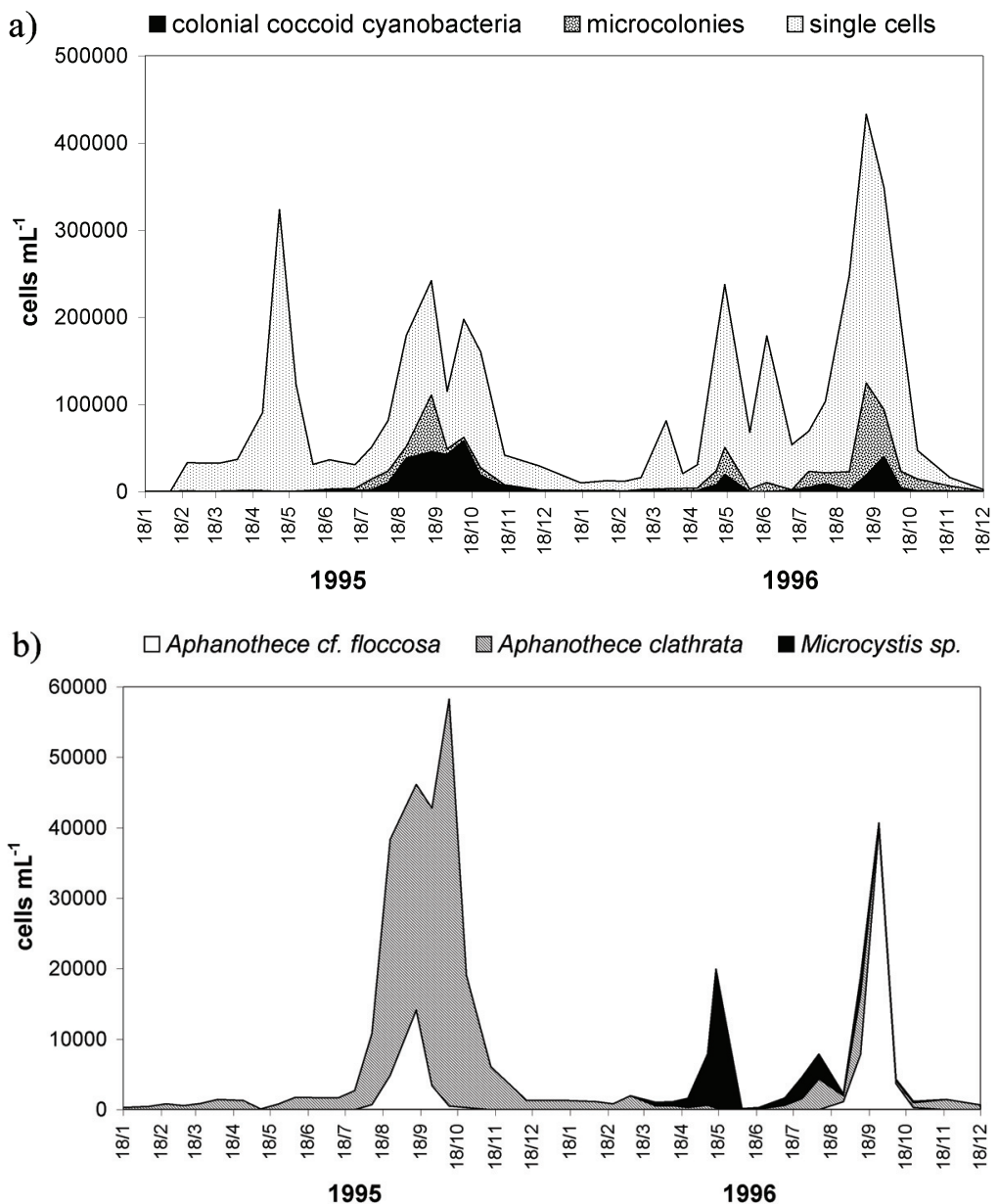

Fig. 3. Seasonal dynamics of: (a) single-cell picocyanobacteria, microcolonies and colonial coccoid cyanobacteria, (b) Aphanothece clathrata, A. cf. floccosa and Microcystis sp., in Lake Maggiore (from Passoni \& Callieri 2000, modified).

(Komárková 2002; Szelag-Wasielewska 2003; Crosbie et al. 2003c; Mózes et al. 2006; Ivanikova et al. 2007). Such a variety of morphotypes reflects a genotypic diversity among Pcy communities that accounts for the different Pcy composition observed in spring and summer assemblages (Callieri et al. 2007; Caravati 2008) (Fig. 4).

Using quantitative PCR, a sort of rapid succession of individual clades of Pcy shows the patchy structure of the community over quite small spatial/temporal scales (Sánchez-Baracaldo et al. 2008). At the same time the co-existence of genetically and physiologically diverse Synechococcus spp. found in the pelagic zone of Lake Constance (Postius \& Ernst 1999; Ernst et al. 2003) indicates possible niche partitioning exploited by the different strains. In marine systems distinct Pcy lineages have also been shown to partition between waters having different environmental characteristics (Fuller et al. 2006), a feature evident over large spatial scales (Zwirglmaier et al. 2007, 2008). In the Sargasso Sea the community composition of Pcy varied during the season with the highest numbers of Synechococcus in spring and Prochloro- coccus in summer and autumn (DuRand et al. 2001). I suggest that the new perspective of habitat-related distribution pattern of Synechococcus proposed for Lake Constance (Becker et al. 2007) and North Patagonian Andean lakes (Caravati et al. 2010) could be generalized to other aquatic systems.

Furthermore, there is strong evidence that Pcy of the cyanobacterial evolutionary lineage VI sensu Honda et al. (1999) are not exclusively pelagic organisms, but can also inhabit periphytic biofilm in the euphotic zone of temperate lakes (Becker et al. 2004). We should integrate our knowledge of Pcy diversity in pelagic and littoral zone habitats to better explain the dominance of certain genotypes in the water column, because the adaptability of these microorganisms may likely be the key feature for their ubiquity (Becker et al. 2004).

\subsection{Spatial dynamics}

Studies of the vertical distribution of populations of Pcy have provided important information about their response to changing physical and biological variables within the euphotic zone. Though Pcy cells are small and their settling rate negligible, their abundance and 

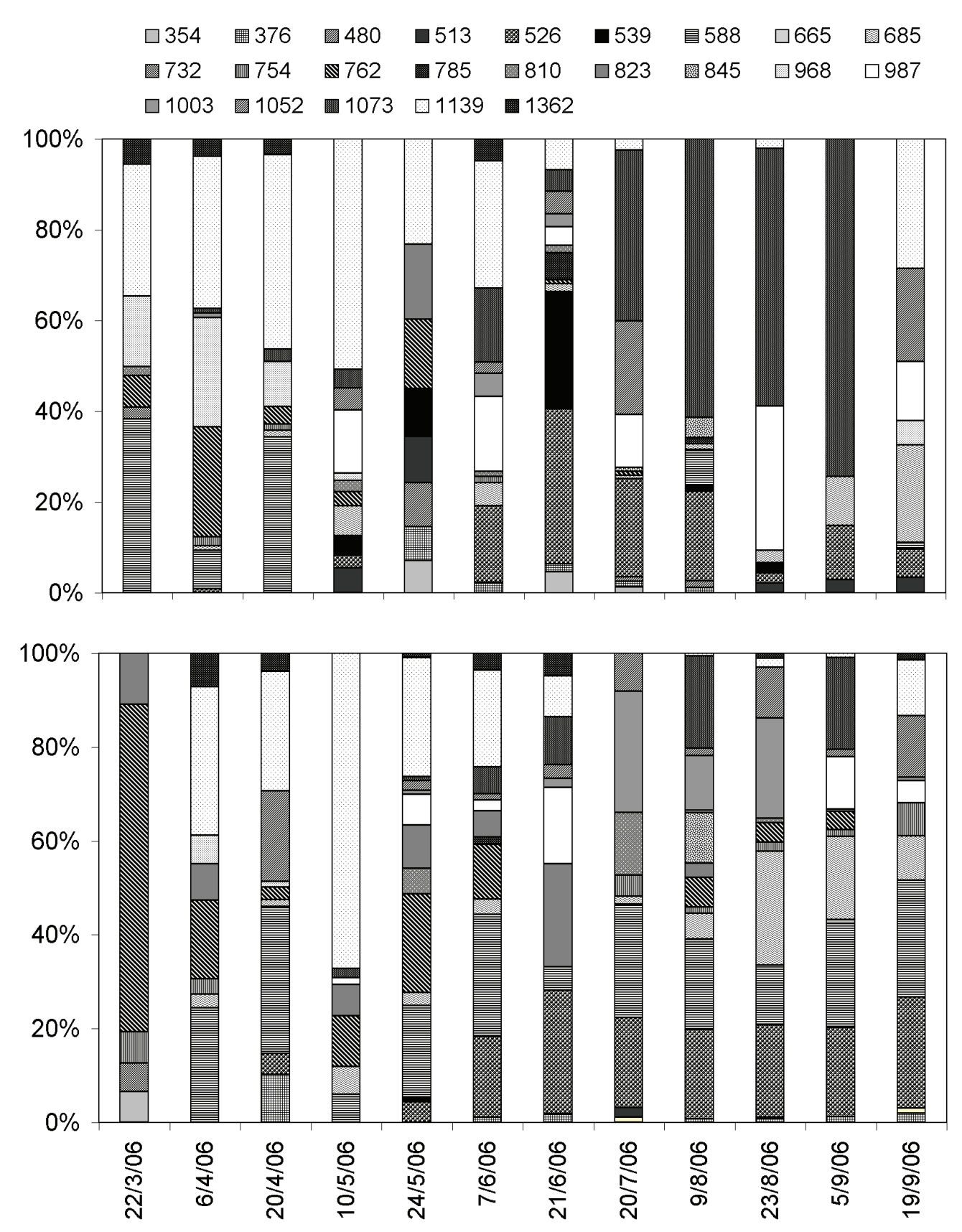

Fig. 4. Dynamics of the percentage of the Operational Taxonomic Units (OTU) of Pcy in Lake Maggiore obtained with ARISA on the ITS-1 (3 m: upper panel, 20 m: lower panel) (from Caravati 2008).

distribution within the water column can change rapidly with different thermal and light regimes, and to the presence of predators or viruses (Pernthaler et al. 1996; Muhling et al. 2005). Water column depth, which is often inversely related to the trophic state of the lake, is an important indicator of the presence of Pcy and/or of its abundance relative to larger species of phytoplankton.

Deep, clear oligotrophic lakes typically support Pcy comprising mainly PE-rich cells; on the contrary PCrich cells prevail in shallow, turbid lakes (Callieri \& Stockner 2002). This disparity in the distribution of PE- and PC-rich cells is due to their characteristic spectral signature (Everroad \& Wood 2006), which has been associated with particular underwater light quality (e.g., Hauschild et al. 1991; Vörös et al. 1998). In the bluegreen North Patagonian lakes (Pérez et al. 2002), PErich cells typically dominate the Pcy that forms deep chlorophyll maxima (DCM) at the base of the euphotic zone (Callieri et al. 2007). In Lake Baikal at offshore stations the Pcy are mainly PE-rich cells, whereas PCrich cells are found at near shore stations (Katano et al. 2005,2008 ), suggesting water quality differences in 


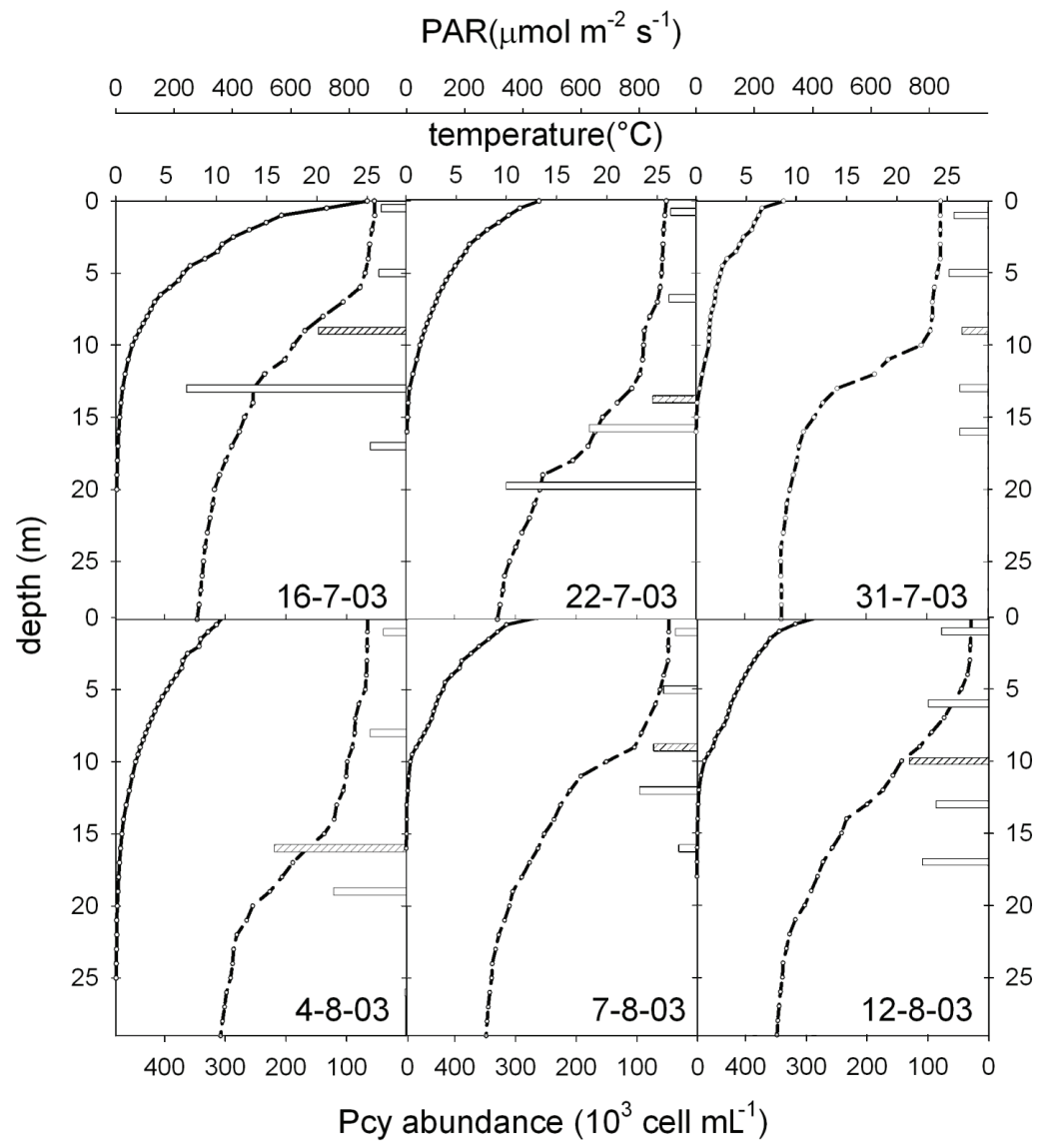

Fig. 5. Six vertical profiles of Pcy abundance, temperature and PAR in Lake Maggiore, during 30 days of summer stratification (Callieri C. and Oboti L., unpublished data). In solid line the photosynthetic active radiation (PAR), in dashed line the temperature, and in histogramms the Pcy abundances. The striped histogramms refer to the depth of thermocline, below there are depths of around $0.1-4 \%$ of surface PAR, above depths of around $25-75 \%$ of surface PAR.

various zones of the lake. Similar situations have been described for Lake Balaton where in the eastern basin PE-rich cells dominate, while in the western basin PCrich cells are dominant (Mózes et al. 2006). It is the establishment of a pronounced thermocline at depth which likely favours the development of DCM, largely made up of Pcy which are suited both to low nutrient and light conditions (Modenutti \& Balseiro 2002; Gervais et al. 1997; Camacho et al. 2003; Callieri et al. 2007). In Lake Tahoe Pcy dominated in the nutrient deficient upper water column during the stratified season, in a distinct vertical niche with respect to picoeukaryotes which peaked at DCM (Winder 2009), as has been found in the Oceans (Vázquez-Domínguez et al. 2008). The dynamics of DCM formed by Pcy is quite unstable and its duration is unpredictable, depending upon the strength of hydrodynamic and biotic interactions. A good example is provided by Pcy communities in Lake Maggiore where DCM can appear, and also suddenly disappear, in just a few days (Fig. 5).

Further, it has been shown that the interaction of different biotic and abiotic factors within the water column can affect Pcy vertical distribution patterns, with peaks of abundance in the lower metalimnion and upper hypolimnion of Lake Stechlin (Padisák et al. 1997, 1998); in the metalimnion, beneath the steepest part of the thermocline, in Lake Constance and Lake Maggiore (Weisse \& Schweizer 1991; Callieri \& Pinolini 1995); in the metalimnion of Lake Baikal (Nagata et al. 1994); and in the epilimnion of Lake Biwa (Maeda et al. 1992), Lake Kinneret (MalinskyRushansky et al. 1995) and Lake Alchichica, Mexico (Peštová et al. 2008).

Microcolonies followed the Pcy single-cell vertical abundance in Lake Maggiore, with a significant correlation between the two distribution patterns in summer (Passoni \& Callieri 2000). This provides further evidence of the importance of a common approach to the ecology of single-cells and microcolonies in freshwaters.

\section{ECOLOGICAL ASPECTS OF PCY COMMUNITY}

\subsection{Morphometry and temperature}

In order to interpret Pcy single cells and microcolonies dynamics in freshwaters it is imperative to take into consideration the morphometric characteristics and thermal regime of a lake. The community composition of the Pcy can strongly depend on lake typology and 
morphogenesis. In a survey covering 45 lakes and ponds, Camacho et al. (2003) found that picocyanobacterial development was favoured by the stability of the vertical structure of the lake; that is by the inertial resistance to complete mixing owing to vertical density differences and to a long hydrological retention time. In lakes with relatively high water inflow and short retention time, Pcy are scarce. Far from this situation are deep lakes with a complex basin morphometry such as large sub-alpine lakes. In one of these lakes (Lake Maggiore, Northern Italy) the Pcy population densities during summer stratification are high but with a pronounced North-South gradient due to a high retention time and peculiar characteristics along the lake axis (Fig. 6) (Bertoni et al. 2004). Lake Constance, with a different basin morphometry, has a less pronounced gradient (Weisse \& Kenter 1991).

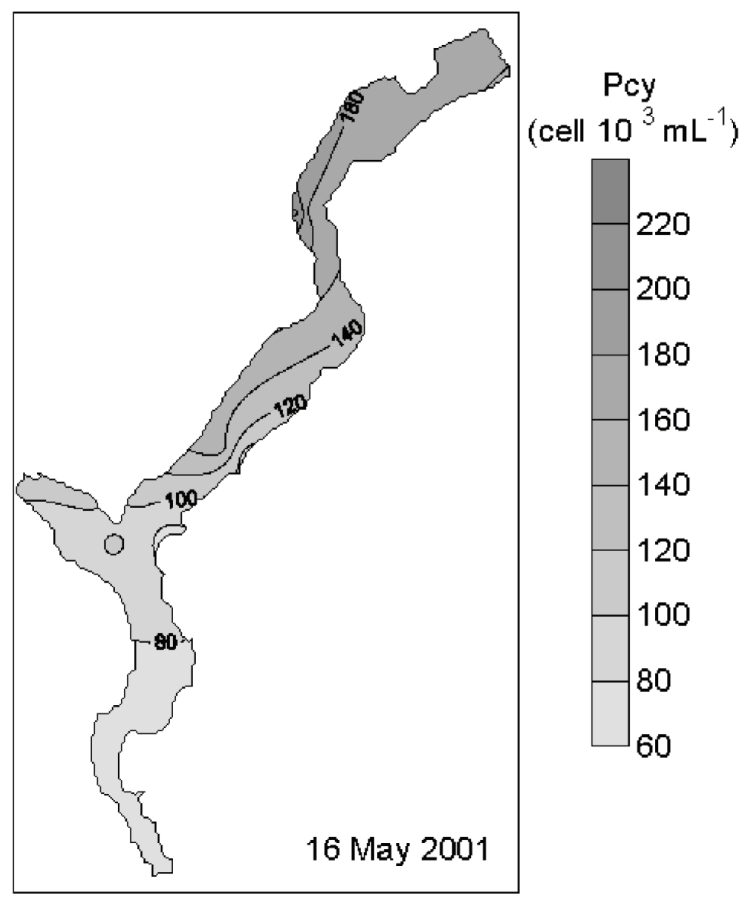

Fig. 6. Map of the spatial heterogeneity of picocyanobacteria (Pcy) abundance in Lake Maggiore during spring sampling. The Northern basin of the lake has a lower contribution of total nitrogen and total phosphorus from the drainage basin respect to the other part of the lake (Bertoni et al. 2004, modified).

Pcy composition and abundance vary conspicuously among shallow lakes, with a strong dependence on lake trophic condition (Søndergaard 1991; Stockner 1991), on lake altitude (see Straškrabová et al. 1999, and references cited therein), on oxidized-reduced conditions (Camacho et al. 2003), and on the presence of dissolved humics (Drakare et al. 2003). Therefore it is very difficult to predict Pcy abundance in shallow lakes without considering the physico-chemical characteristics of their waters. In a study of shallow humic lakes of the Boreal Forest Zone, Jasser \& Arvola (2003) found Pcy to be light and temperature limited whereas in humic Swedish lakes dissolved organic carbon (DOC) concentration was the factor most influencing Pcy composition (Drakare et al. 2003).

The effect of lake thermal structure on the abundance and dynamics of Pcy must take into consideration both the effect of temperature per se and the water mass movements due to the formation of density gradients. In general the increase of temperature enhances the potential growth rate of phytoplankton, increasing the reaction rate of RUBISCO (Beardall \& Raven 2004). Marine Synechococcus reacts promptly to the temperature increase in laboratory experiments (Fu et al. 2007), and in a five year study on Lake Balaton Pcy abundance was positively correlated to water temperature (Vörös et al. 2009). Nevertheless the influence of temperature on the abundance of Pcy in the field is difficult to separate from seasonality effects and biogeographic location. The general consensus that temperature is the driving force for growth and development of many different microorganisms does not apply so plainly for Pcy in the field. In diverse marine habitats Li (1998) found a direct relation of the Pcy yearly mean abundance with temperature below $14{ }^{\circ} \mathrm{C}$, and noticed that above $14{ }^{\circ} \mathrm{C}$ nitrate concentrations were very low and therefore could replace temperature as the most significant factor affecting Pcy growth. At higher temperatures, other factors can become dominant and control Pcy growth. Weisse (1993) proposed the importance of temperature as triggering the onset of Pcy growth in marine and freshwaters, but not for regulating their population dynamics. In Lake Maggiore the maximal concentrations of Pcy were observed at an optimum temperature of between $18{ }^{\circ} \mathrm{C}$ and $20{ }^{\circ} \mathrm{C}$ and at the depth of the thermocline (Callieri \& Piscia 2002). In this case thermal conditions were important, not only for the ambient water temperature per se, but for the maintenance of a density gradient resisting further settlement and the further deepening of the Pcy peak (Callieri 2008). In general it is possible to state that vertical density gradients in lakes have a very profound effect on the distribution and diversity of Pcy abundance peaks reported in the metalimnion, upper hypolimnion and mixolimnion.

\subsection{Nutrients}

Nutrient co-limitation can occur in oligotrophic systems (Mills et al. 2004), where more than one nutrient may effectively co-limit biomass production (Mackey et al. 2009). Thus, past assumptions about whether the $\mathrm{N}$ or $\mathrm{P}$ is the proximate or ultimate nutrient limiting the productivity of phytoplankton populations in both marine and freshwater systems are re-opened to debate.

As regard Pcy it may be inferred from the Stockner model that as lakes or oceans become more nutrient 


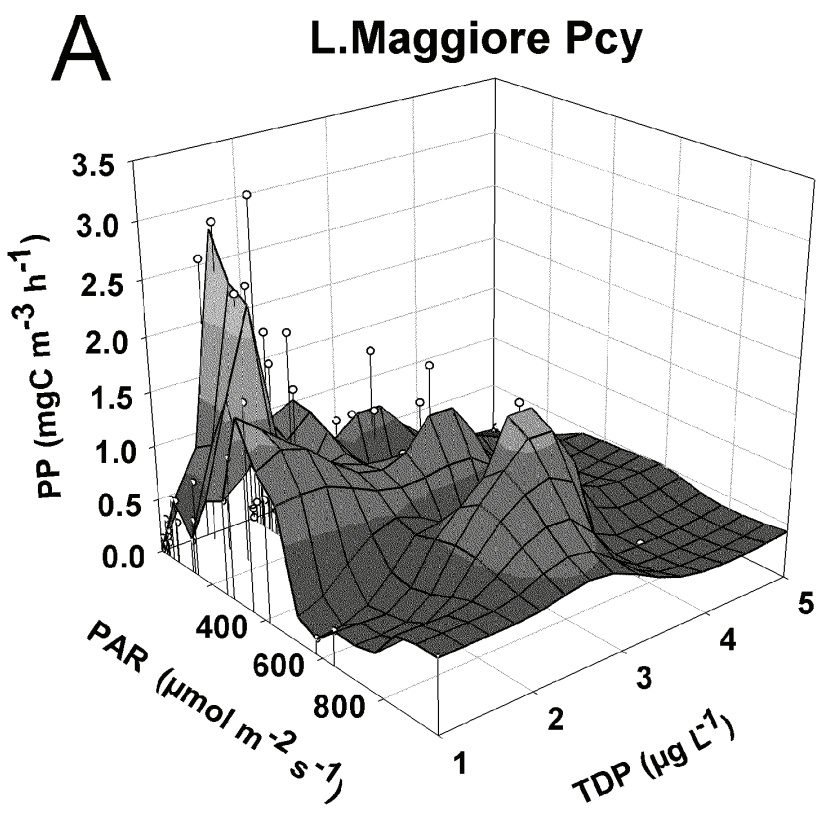

\section{B North Patagonian Lakes Pcy}

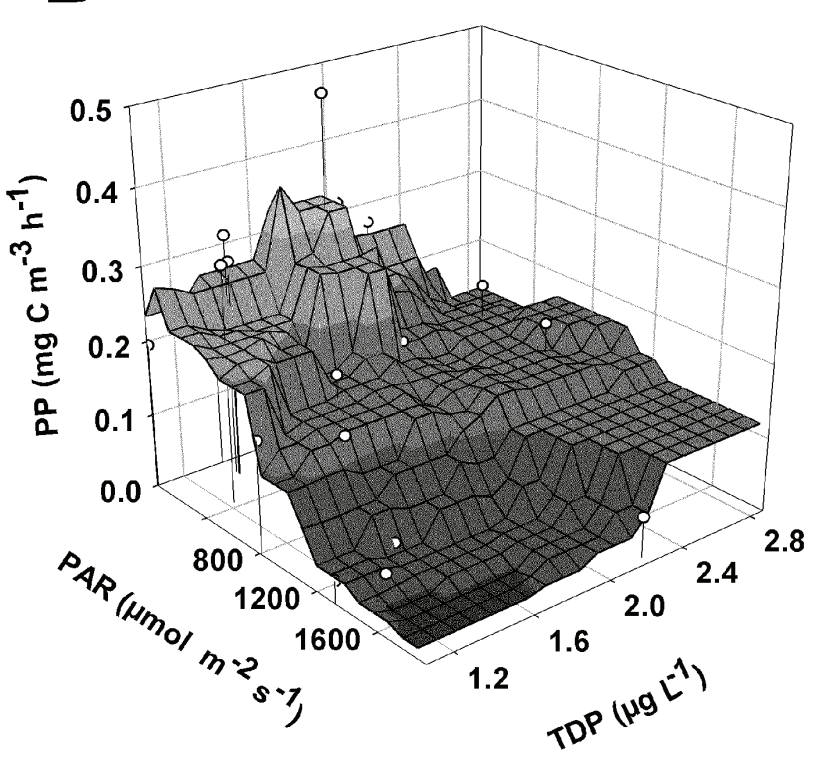

Fig. 7. Multiple linear regression analysis of the Pcy primary production (PP) vs irradiance (PAR) and P (TDP) in: (A) Lake Maggiore, (B) six North Patagonian Lakes (partly from Callieri et al. 2007, modified).

depleted, i.e. oligotrophic, then the greater the importance and relative contribution of Pcy to total autotrophic biomass (Bell \& Kalff 2001). The success of Synechococcus spp. in oligotrophic systems can also be explained by their high affinity for orthophosphate (Moutin et al. 2002) and their maximum cell specific Puptake rates that are competitively superior to algae and other bacteria under a pulsed supply (Vadstein 2000). Actually it has been demonstrated that growth rates of marine Pcy, under limitation by $\mathrm{NH}_{4}{ }^{+}, \mathrm{PO}_{4}{ }^{3-}, \mathrm{Fe}$ or light, are seldom completely stopped; moreover, cell quotas are low as can be expected for such small cells (Timmermans et al. 2005).

An alternative explanation for the relative success of Pcy to grow at low inorganic $\mathrm{P}$ concentrations is given by the ability of cells to utilise, in addition to $\mathrm{PO}_{4}{ }^{3-}$, organic sources of phosphate. Under orthophosphate limitation, algae hydrolyse ambient organic phosphates using extracellular phosphatases and transport the orthophosphate thus liberated into their cells (Jansson et al. 1988). The extracellular phosphatase activity (APA) in several phytoplankton species has been demonstrated by the enzyme-labelled fluorescence (ELF) technique (Nedoma et al. 2003; Štrojsová et al. 2003).

There are other alternative ways for Pcy to overcome P limitation. Two pathways are of interest: one has been discovered from the presence of genes necessary for phosphonate utilization in the genome of Pcy (Palenik et al. 2003). This suggests that in P limiting conditions Synechococcus is able to survive utilizing this refractory form of DOP, derived also from a common herbicide. The other alternative derives from the ability of marine cyanobacteria to substitute sulphate
$\left(\mathrm{SO}_{4}{ }^{2-}\right)$ for $\mathrm{PO}_{4}{ }^{3-}$ in lipids, thus minimising their phosphorus requirement by using a 'sulphur-for-phosphorus' strategy (Van Mooy et al. 2006).

There is evidence that ammonium is the preferred form of nitrogen for Synechococcus in culture (Glibert \& Ray 1990), but when ammonium is exhausted Synechococcus can take up nitrate, thanks to a regulatory mechanism that can induce expression of nitrate reductases (Bird \& Wyman 2003). Also, under severe N-limitation Pcy can alternatively use the nitrogen reserve that exists in phycobiliproteins as amino acids storage molecules (Grossman et al. 1993).

The success of Pcy under low light conditions is tightly coupled with competition for limiting nutrients. Good evidence on the interplay between P, irradiance and primary production of Pcy and how it is mediated in the field is difficult to envisage, but some clues come from the comparison of six ultra-oligotrophic North Patagonian lakes and from the sub-alpine Lake Maggiore (Fig. 7) (Callieri et al. 2007). In the ultraoligotrophic lakes Pcy production was inversely significantly related to PAR but not to $\mathrm{P}$, indicating that in such extremely nutrient deplete ecosystems, low $\mathrm{P}$ concentrations were not the limiting resource driving Pcy production. Conversely, in the oligo-mesotrophic Lake Maggiore both P and light were not significantly correlated to Pcy production. One interpretation of these results is that high irradiance is likely photo-inhibiting Pcy production and hence is the key driving variable and not phosphorus concentration. Similar finding are reported by Lavallée \& Pick (2002) who found a lack of correlation between pico-phytoplankton growth rates and any form of dissolved phosphorus. 


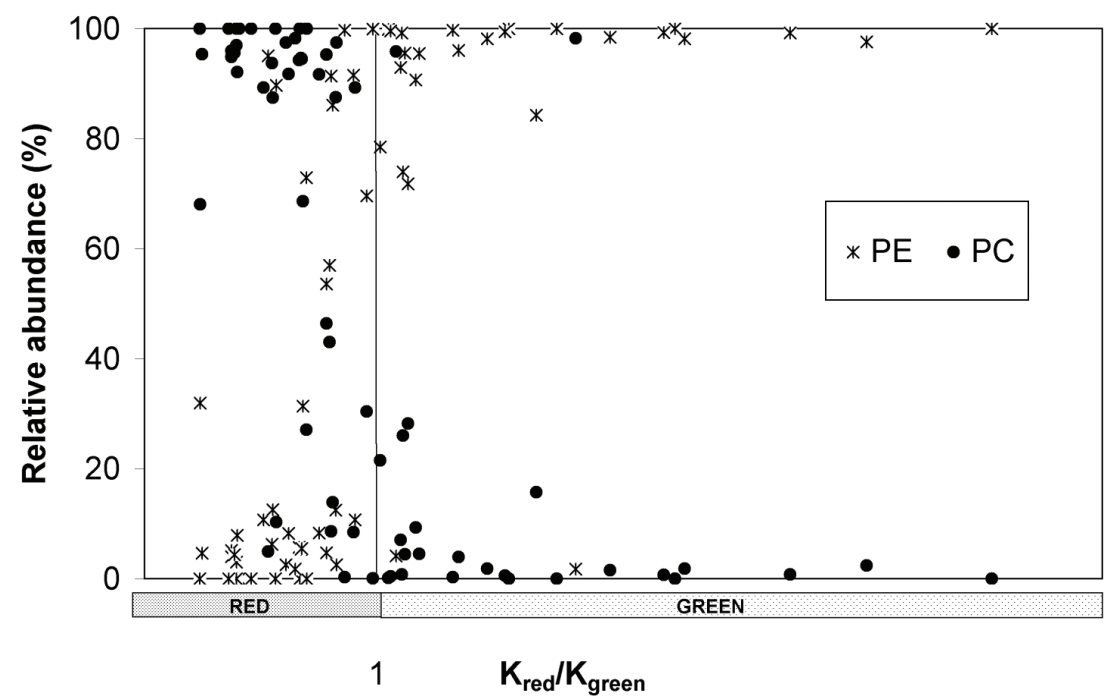

Fig. 8. Relative abundance of PC-cells and PE-cells in different aquatic systems in relation to the underwater light climate expressed as the ratio between the extinction coefficient of red and green wavelengths $\left(\mathrm{K}_{\mathrm{RED}} / \mathrm{K}_{\mathrm{GREEN}}\right)$. When the $\mathrm{K}_{\mathrm{RED}} / \mathrm{K}_{\mathrm{GREEN}}$ ratio is $>1$ the extinction of red light is high and the dominant underwater light is green. Very low values of $\mathrm{K}_{\mathrm{RED}} / \mathrm{K}_{\mathrm{GREEN}}$ ratio indicate a red dominant underwater radiation (modified from Vörös et al. 1998).

\subsection{Light}

Light is well known as an important factor in niche differentiation for Pcy and can modulate the balance between single-cells and microcolonies. The response of Pcy to different light intensity has been studied both in laboratory experiments and in situ, and it has been shown that the optimum growth rate of Synechococcus occurs at low light intensities, notably at a quantum flux of $45 \mu \mathrm{E} \mathrm{m} \mathrm{m}^{-2} \mathrm{~s}^{-1}$ where their highest growth has been observed (Morris \& Glover 1981). These findings agree with field observations where the maximum peak abundance has been found deep in the Atlantic mixed layer (Glover et al. 1985), and in the DCM (deep chlorophyll maximum) of Lake Stechlin (Gervais et al. 1997) and of North Patagonian ultra-oligotrophic Andean lakes (Callieri et al. 2007). In lakes worldwide Pcy have been found at a variety of depths and light irradiance (Nagata et al. 1994; Callieri \& Pinolini 1995; Callieri \& Piscia 2002), confirming the classification of Synechococcus as a euryphotic organism (Kana \& Glibert 1987). One explanation of Pcy tolerance and adaptation to high irradiance is the identification of a process that prevents photo-damage in open ocean Pcy by maintaining oxidized PSII reaction centres, channeling the electrons from PSI to oxygen through a specific oxidase (Mackey et al. 2008). As a results of this process Pcy possess an efficient mechanism for dissipating PSII excitation energy, decreasing any potential photo-damage. Nevertheless the relative phylogenetic complexity of the Synechococcus and Cyanobium genera does not presently permit the simple discrimination of high light- and low light-adapted ecotypes, as has been attained for Prochlorococcus (Scanlan \& West 2002; Ahlgren \& Rocap 2006).
Synechococcus ecotypes exhibit differences in their accessory pigments that affect their adaptation to spectral light quality. It was found that in highly coloured (humic) lakes, non-phycoerythrin cells dominated numerically, while in clearer, oligotrophic hard-water lakes, phycoerythrin-rich cells were the most abundant (Pick 1991). The influence of underwater light quality on the selection of Pcy types having different pigment content has been studied in many aquatic systems, covering a wide spectrum of trophic states and underwater light quality (Vörös et al. 1998; Stomp et al. 2007). Vörös et al. (1998) found that the percentage of PE-rich cells in the total Pcy community (PE + PC) increased with increasing values of the $\mathrm{K}_{\mathrm{RED}} / \mathrm{K}_{\text {GREEN }}$ (vertical attenuation coefficient) ratio (Fig. 8). When this ratio is $>1$ the extinction of the red light is high and therefore the dominant underwater light is green (and blue). On the other hand very low values of this ratio indicate a red dominant underwater radiation. This finding has been resumed by Stomp et al. (2007) who considered turbidity instead of light climate. Light quality is actually the primary reason of the prevalence of PC- or PErich Pcy, due to their different pigment composition.

In laboratory experiments, it has been shown that Pcy grow better when they have a phycobiliprotein whose absorption spectrum is complementary to that of the available light (Callieri et al. 1996) and subsequent experiments showed that PE-rich cells prevail in green light and PC-rich cells in red light but when grown together in white light, can co-exist, absorbing different parts of the light spectrum (Stomp et al. 2004). The importance of red light for phycocyanin and biomass production has been shown in laboratory experiments with a PC-rich Synechococcus strain (Takano et al. 1995), while blue and green wavelengths of light are 
used more efficiently than red of similar intensity by PE-rich Synechococcus (Glover et al. 1985).

The pigment composition of Pcy represents a characteristic spectral signature that can define individual strains, but closely related strains can have different pigment composition (Everroad \& Wood 2006). In particular both pigment types have been found in several non-marine Pcy clusters (Crosbie et al. 2003a). A new clade, sister to Cyanobium, was recently reported from oceanic waters, based upon phylogenetic analysis of concatenated 16S rDNA and rpoC1 data sets (Everroad \& Wood 2006). This large clade includes both PE-rich and PC-rich strains. Similarly, marine cluster B (MC-B) also contains PE-rich and PC-rich strains, and this cluster is polyphyletic, consisting of at least 2 different subclusters (Chen et al. 2006). The phylogeny derived from the $c p c \mathrm{BA}$ operon of the green PC pigment was better able to separate differently pigmented Pcy than $16 \mathrm{~S}$ rRNA-ITS phylogeny (Haverkamp et al. 2008). The ecological implication of these findings is that Synechococcus from different lineages can occupy different niches; or alternatively, if the environment offers greater variability and more suitable niches, like in the Baltic Sea (Haverkamp et al. 2009) or in Lake Balaton (Mózes et al. 2006), they can coexist.

Laboratory experiments with freshwater strains from different phylogenetic groups acclimated at low and medium irradiance, showed that photosynthetic responses are strain-specific and sensitive to photo-acclimation (Callieri et al. 2005; Moser et al. 2009) (Fig. 9). PE-rich Pcy from Group B, subalpine cluster I (sensu Crosbie et al. 2003a), are more sensitive to photo-acclimation than PC-rich cells from Group I and from Group A, Cyanobium gracile cluster. Therefore eco-physiological differences seem to be more related to the pigment type. Nevertheless the extent of photoadaptation is strain-specific and depends on the duration of the photo-acclimation (Moser et al. 2009).

\subsection{Ultraviolet radiation (UVR)}

Picoplankton are thought to be particularly vulnerable to UVR because: 1) their small size does not permit the intracellular production of sunscreen compounds (Garcia-Pichel 1994); 2) the small 'package' effect leads to higher pigment-specific absorption (Morel \& Bricaud 1981) and 3) the distance between the cell surface and the nucleus (DNA) is shortened and the DNA damage induced by UV-B is increased. Thymine dimers like cyclobutane pyrimidine dimer (CPD) are frequently built upon DNA lesions under UV-B radiation and have been recovered in marine phytoplankton (Buma et al. 1995) and in Argentinian lakes (Helbling et al. 2006).

Although the higher vulnerability of picoplankton is theoretically predictable, contrasting results have been obtained in field studies. Laurion \& Vincent (1998) studying size-dependent photosynthesis in a sub-arctic lake have shown that cell size is not a good index of
UVR sensitivity. Further, they indicated that Pcy are less sensitive to UVR fluxes and that genetic difference between taxa, more than size, are important in determining the tolerance to UVR; while other authors obtained evidence of an higher vulnerability of smaller algae to UVR (Kasai et al. 2001; Van Donk et al. 2001).

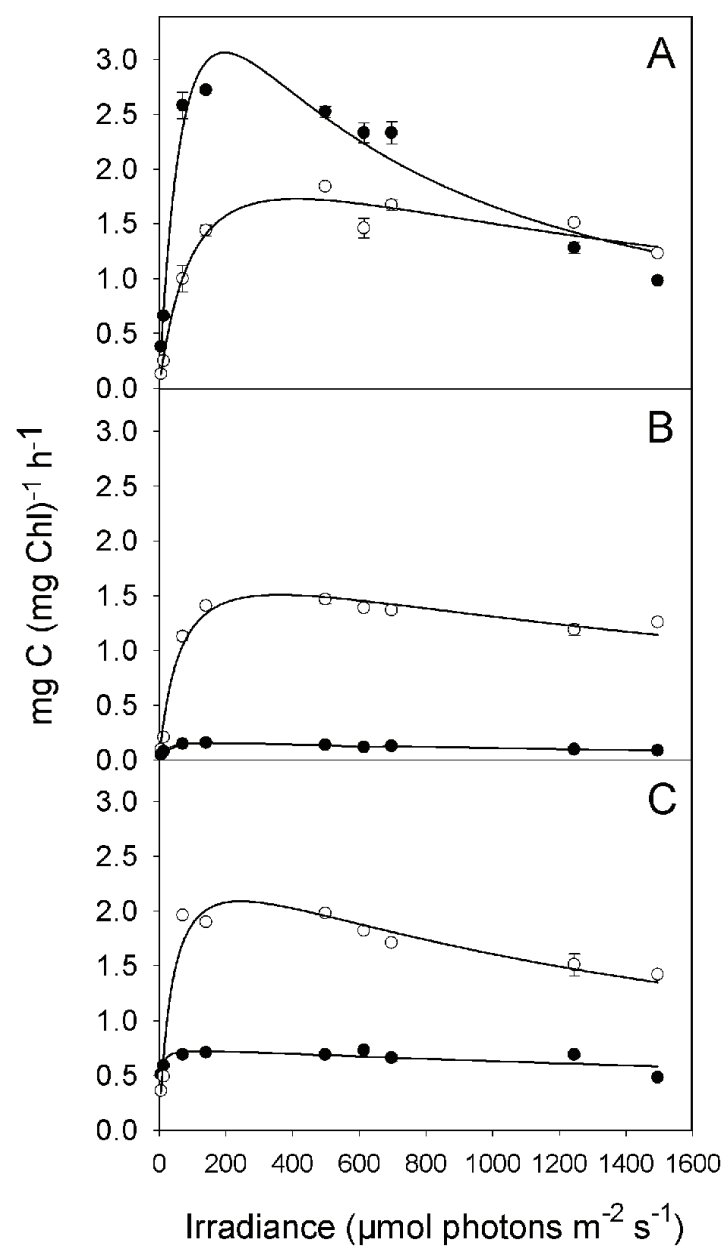

Fig. 9. P/E curves of three Pcy strains: (A) PE-cells MW4C3 from the Group B, Subalpine cluster; (B) PC-cells MW100C3 from Group I; (C) PC-cells BO8801 from Group A, Cyanobium cluster. Open symbols refer to medium light acclimation $\left(100 \mu \mathrm{mol} \mathrm{m} \mathrm{m}^{-2} \mathrm{~s}^{-1}\right)$, filled symbols refer to low light acclimation $\left(10 \mu \mathrm{mol} \mathrm{m} \mathrm{s}^{-2}\right)$. (from Moser et al. 2009, modified).

A high Pcy sensitivity to UVR radiation in comparison to nano-phytoplankton was observed in the biological weighting functions (BWF) in a high altitude alpine lake by Callieri et al. (2001). A possible interpretation of these contrasting results is that small cells are likely more susceptible to DNA damage than large cells but they are able to acclimate faster, within hours (Helbling et al. 2001), and are more resistant to photosystem damage (Villafañe et al. 2003). 
The spectral quality of the UVR exposure, its duration and photon flux density, strongly influences the effect on phytoplankton communities (Harrison \& Smith 2009). The damaging power of radiation generally increases from PAR through UV-A into the UV-B wavebands, but this general pattern may still be questioned (Harrison \& Smith 2009). There is evidence that many aquatic organisms react promptly to UV-B stress by producing protective substances such as mycosporine-like amino acid compounds (MAAs) (Sinha \& Hader 2008), which have absorption maxima ranging from 310 to $359 \mathrm{~nm}$ (Carreto et al. 1990; Karentz et al. 1991). In particular cyanobacteria react in response to UV-A radiation by producing an extracellular yellowbrown pigment - scytonemin, that absorbs most strongly in the UV-A spectral region $(315-400 \mathrm{~nm}$ ) (GarciaPichel \& Castenholz 1991; Dillon et al. 2002). The sunscreen capacities of MAAs and scytonemin are higher if they are present concurrently, and their production is considered an adaptive strategy of photo-protection against UVR irradiance (Garcia-Pichel \& Castenholz 1993). Also it is recognized that the UV-B induced production of CPD is counterbalanced by repair mechanisms based on the production of enzymes known as photolyases (Jochem 2000).

Therefore aquatic organisms have numerous mechanisms of protection against UVR which influence their global community responses in nature. Recently it has been recognized that many of the effects of solar UVR are caused by wavelengths in the UV-A range, which are not affected by changes in stratospheric ozone (Sommaruga 2009). The higher photo-inhibiting effect of UV-A than UV-B on different size fractions of phytoplankton has been described in several different lakes (Callieri et al. 2001; Villafañe et al. 1999; Callieri et al. 2007) and in marine habitat as well (Villafañe et al. 2004; Sommaruga et al. 2005). Callieri et al. (2001) explain the negligible impact of UV-B on in situ phytoplankton production with the lower weighted irradiance brought about by the high $\mathrm{K}_{\mathrm{d}}$ at short wavelengths and low incident flux, whereas with UV-A the weighted irradiance is higher due to a greater incident flux and lower $\mathrm{K}_{\mathrm{d}}$.

Mixing is an important factor affecting the degree of plankton exposure to UVR. Vertical mixing transports the cells to depth where active repair takes place and subsequently re-exposes them to higher UVR, upon transport again to near surface depths. Species which form surface blooms, like colonial Microcystis aeruginosa, can also withstand high UVR, synthesizing carotenoids and MAAs (Liu et al. 2004). To explain the resistance of colonial Pcy to UVR it is interesting to note that the colonial morphotype of Microcystis can synthetize substances such as D-galacturonic acid, which is the main component of the slime layer of Microcystis (Sommaruga et al. 2008), and which may hence provide a protective function. In Nostoc commune UV-B expo- sure induced the synthesis of a glycan sheath around the filaments to provide a matrix for the MAAs (EhilingSchulz et al. 1997). Similarly microcolonies, here considered as transitional forms from single-cell to colonial, may have a selective advantage under UVR exposure due to the presence of a sheath matrix. To better understand the role of microcolonies in lakes Callieri \& Bertoni (in preparation) used a PE-rich Synechococcus strain which does not form aggregates in culture, and exposed the strain to different levels of UVR and PAR radiation under controlled conditions (Fig. 10). They observed that the culture previously acclimated to high light (HL) did not form microcolonies, even if exposed to UVR, but the culture acclimated to low light (LL) reacted to UVR by forming microcolonies, likely finding a refuge through a morphological adaptation, inclusive of slime layer protection, similar to that noted in Microcystis (Sommaruga et al. 2008). Therefore, in the equilibrium between single cells $v s$ microcolonies or even larger colonial morphologies, the importance of solar radiation (UVR and PAR) should not be underestimated but considered together with other important factors like the nutrient status of the ecosystem.

\subsection{Biotic interactions}

Heterotrophic and mixotrophic nanoflagellates and small ciliates have been recognised as the most important grazers of Pcy (Stockner \& Antia 1986; Christoffersen 1994; Sanders et al. 2000). Despite the importance of ciliate grazing on Pcy in some systems (Šimek et al. 1995), it is generally recognized that among protozoa, both heterotrophic and mixotrophic nanoflagellates are responsible for $90 \%$ of the grazing of Pcy and bacteria; whereas ciliates accounted for only $10 \%$ (Pernthaler et al. 1996b; Callieri et al. 2002). The size of the prey, its morphological characteristics and nutritional value have been indicated as important factors in the selection carried out by the predators (Šimek \& Chrzanowski 1992; Jezberová \& Komárková 2007; Shannon et al. 2007). In particular the involvement of the proteinaceous cell surface (S-layer) as grazing protection has also recently been suggested for freshwater Actinobacteria (Tarao et al. 2009). Morphological characteristics can therefore be considered as group-specific traits and can greatly influence the success of the group in their ecosystems. The presence of a gelatinous matrix in the Pcy microcolonies (like for the larger colonial Pcy), acts as an effective anti-grazing agent. Protozoa grazing and in particular nanoflagellates can influence the characteristics of bacterial and Pcy communities and lead to changes in their structural and taxonomic composition. In a laboratory study, using 37 Synechococcus strains it was clearly demonstrated that prey selection discriminates at the strain-specific level (Zwirglmaier et al. 2009).

The selection of food as described for metazooplankton generally takes place during food capture and 

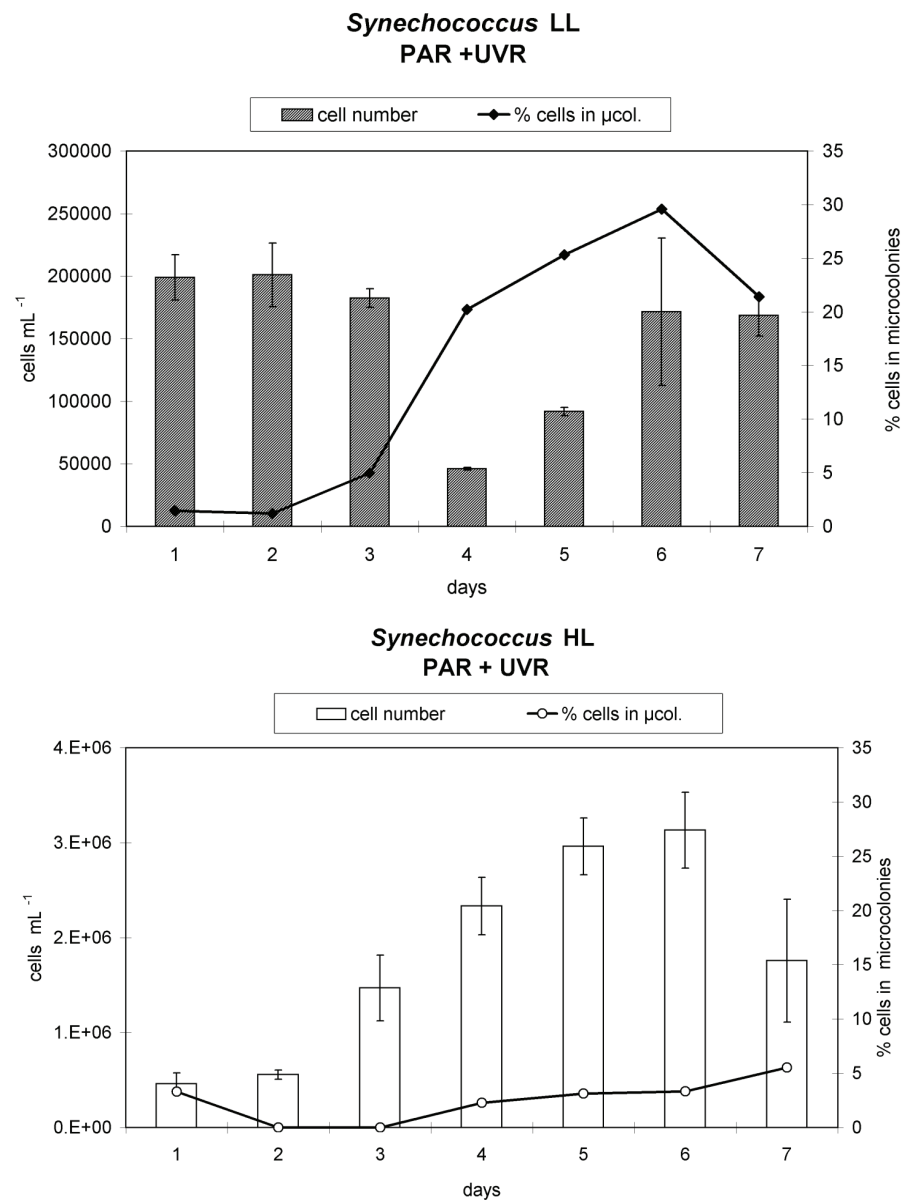

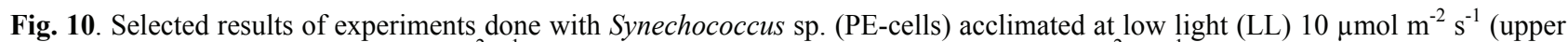
panel) and high light (HL) $100 \mu \mathrm{mol} \mathrm{m} \mathrm{s}^{-1}$ (lower panel) exposed to UV (Q panel $30 \mu \mathrm{W} \mathrm{cm} \mathrm{nm}^{-1}$ ) and HL. The percent of cells in microcolonies increase beginning from the 4 days in the LL culture, but not in the HL (from Callieri \& Bertoni, in preparation).

processing (Porter 1973). According to the theory of 'selective digestion' prey selection takes place inside the food vacuoles (Boenigk et al. 2001). The fate of the prey is decided at the moment of digestion, with the possibility of very fast prey-excretion after the uptake. Knowledge of the mechanism of Pcy consumption and excretion/digestion is species-specific both for prey and predator. Also, amoebae can perform food selection in the food vacuole and excrete the toxic or unpalatable prey items similarly to nanoflagellates (Liu et al. 2006; Dillon \& Parry 2009).

Ciliates and nanoflagellates can also serve as a trophic link between Pcy production and Daphnia production, thereby upgrading the nutritional value of Pcy as a food source by producing essential lipids such as sterols (Bec et al. 2006; Martin-Creuzburg \& Von Elert 2006). Among mesozooplankton, Daphnia has the capacity of feeding on a wide particle size range $(1 \mu \mathrm{m}$ to $50 \mu \mathrm{m})$, filtering Pcy as well (Gophen \& Geller 1984; Stockner $\&$ Porter 1988). An important effect of Daphnia grazing on Pcy functioning was observed in laboratory experiments (Callieri et al. 2004), where there was an increase in $\mathrm{P}$ and $\mathrm{C}$ cell-specific uptake of Pcy and in their photosynthetic efficiency. This increase in activity could have been related to the release of P by Daphnia, which was measured to be around $5 \%$ of the total P-pool per day (Boersma \& Wiltshire 2006). Another possible conjecture is that nutrients are replenished during the passage of Pcy through the digestive tracts of consuming daphnids (Porter 1975; Stockner 1991). There is evidence that nutrient-limited green algae pass through the gut of Daphnia intact and alive (Van Donk $\&$ Hessen 1993) and that during passage some of the $\mathrm{P}$ is released in the gut (Boersma \& Wiltshire 2006).

Among lake studies of Pcy, only a few refer to the impact of copepod grazing, particularly calanoid copepods. It has been shown that copepods have a stronger negative effect on ciliates than do Daphnia (Burns \& Schallenberg 1996) and that top-down effects in the short term are stronger in oligotrophic ecosystems than in eutrophic ones (Burns \& Schallenberg 2001). The mesocosm experiments of Zöllner et al. (2003) showed the structuring and cascading effects of the cladoceran Daphnia hyalina cf. galeata and copepods on microbial food web structure. Copepods prey selectively and efficiently on ciliates and algae in the size range 20 to 40 


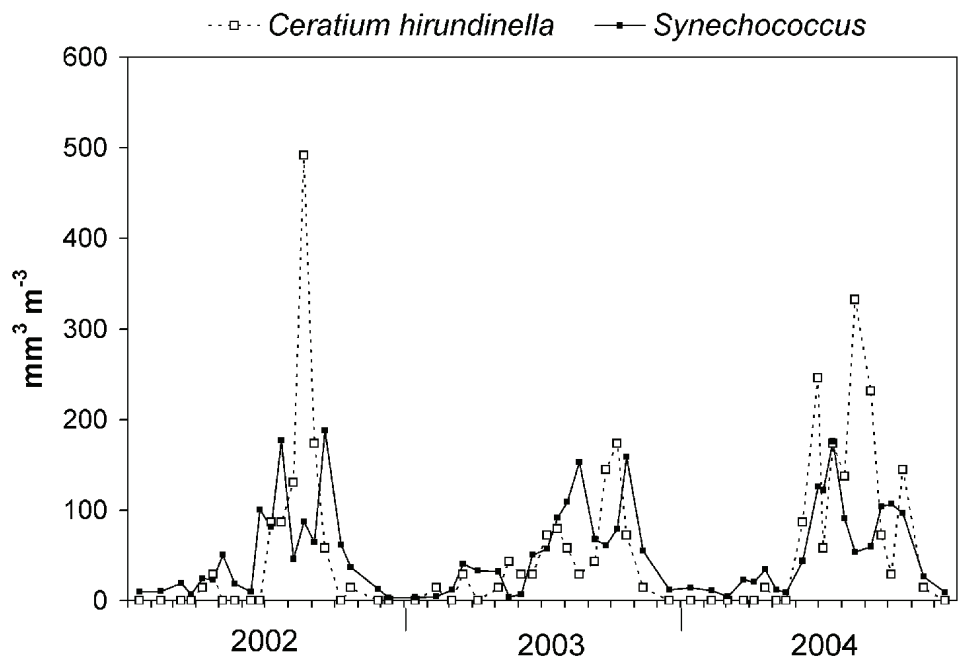

Fig. 11. Seasonal dynamics $(2002,2003,2004)$ of the Synechococcus spp. - Ceratium hirundinella functional association (from Callieri et al. 2006, modified).

$\mu \mathrm{m}$ (Yoshida et al. 2001), thereby triggering a trophic cascade, enabling high numbers of HNF and the potential for a greater mortality of Pcy (Zöllner et al. 2003). Sundt-Hansen et al. (2006) have shown that in marine mesocosms, copepods have a profound structuring effect on the pelagic food web, and thus directly and indirectly, regulate the abundance of Pcy predators. In this way, the strength of the trophic cascade downward to Pcy depends substantially on the structure of the food web and the inventory of zooplankton species present (Gismervik 2006; van Grenberghe et al. 2008).

Rotifers can either act directly on Pcy populations by grazing or indirectly by preying on nanoflagellates and small ciliates (Stockner \& Shortreed 1989; Arndt 1993; Pernthaler et al. 1996a). It has been found that many planktonic rotifers (Keratella cochlearis, K. quadrata, Polyarthra dolichoptera) feed on particles in the size-range 0.5 to $3 \mu \mathrm{m}$, interspecific variation in food selection being dependent on differences in the corona sizes of the consuming species (Ronneberger 1998).

While predation has been recognised as an important top-down structural and dynamic control of Pcy, very little attention has been directed towards the study of other ecological interactions such as symbiosis (Adams 2000). In the sea, the cyanobacterial symbionts (or 'cyanobionts': Taylor 1982) provide an example of proto-cooperation. Foster et al. (2006) used molecular methods to amplify prokaryotic symbiont rRNA sequences from individual marine cells of various marine eukaryotes. The same symbiont was found capable of forming associations with a variety of organisms, thus opening up the possibility of consortial interconnections. Another approach to the study of biological interactions is to consider the in situ occurrence of groups of species that share similar requirements or even show proto-cooperative interaction. The natural co-occurrence and simultaneous increase or decrease in the numbers of some species may indicate the existence of 'functional associations' (Reynolds et al. 2002) that help us to interpret and predict their dynamics. The supposition at the base of such associations is that common morphological or physiological properties offer relative, dynamic advantages of component species of the association. Recently, a new association was proposed that comprises Synechococcus spp. and potentially mixotrophic flagellates e.g., Rhodomonas lacustris, Ceratium hirundinella, Cryptomonas erosa (Callieri et al. 2006). Co-occurrence of Pcy and Ceratium spp. has been reported from mesotrophic lakes (Kasprzak et al. 2000), from Lake Kinneret (Berman et al. 1992) and Lake Maggiore (Callieri et al. 2006). In the latter lake, a three-year study showed a phase of co-existence in which the organisms might each benefit from the association, followed by a phase of predation in which one member of the association prevailed over the other (Fig. 11). At low levels of physical and biological disturbance, the cycle can restart with prey recovery driven by nutrient excretion of phagotrophs. The association indicates that assemblages that form a functional group may not only have similar adaptations and requirements, but can exhibit predator-prey interactions, as was recently shown in a marine lagoon in France where the quasi simultaneous appearance of both Pcy and the dinoflagellate Alexandrium catenella was observed (Collos et al. 2009). These authors hypothesised that Pcy can make up for a particulate nitrogen form during periods of limiting nutrients, thus providing $A$. catenella an ecological advantage over strictly autotrophic phytoplankton. The co-domination of a desirable prey organism, such as Synechococcus with its potential grazers opens up new perspectives on the interaction between the ecological categories of phytoplankton and the components of the microbial food web. We cannot refrain from conjecturing that these functional associations may be an 
advanced phase of a symbiotic association of cyanobacteria with eukaryotic plankton hosts, similar to those observed in the ocean (Carpenter \& Foster 2002; Foster et al. 2006).

In the consideration of biological interactions, it is also opportune to refer to viral infections (Weinbauer 2004). The occurrence of viruses that infect Synechococcus is widespread and there is agreement that phages exert a significant selection pressure on Synechococcus (Mann 2003). Cyanophages are ubiquitous in aquatic environments, and can occur at abundances in excess of $10^{6} \mathrm{~mL}^{-1}$ (Suttle 2000). Recent findings indicate that cyanophage infections can exert a major influence on the direction of Pcy succession in the sea (Muhling et al. 2005), and that marine viruses can act as intermediates for exchanging genes (Zeidner et al. 2005). Transduction is the phage-mediated gene transfer between a donor and a host, and has been recognized as is an important factor for bacterial evolution (e.g., Doolittle 1999). In three peri-alpine lakes viral impact on Pcy exceeded predation in autumn, but was highly variable throughout the early season (Personnic et al. 2009b). However, the interplay between viruses and nanoflagellates and their control of prokaryotes is not completely understood, largely due to a lack of knowledge of the direct interactions of viruses on predators and vice-versa (Jacquet et al. 2007; Massana et al. 2007; Pradeep-Ram \& Sime-Ngando 2008).

The extent of lysogeny in 19 freshwater Synechococcus strains indicated a high level within PC-rich Synechococcus (Dillon \& Parry 2008). These authors found that the majority of cyanophages in the eutrophic lake they studied were temperate, that is they exist in a lysogenic association with their hosts. In the majority of the strains cell lysis by the phage was only triggered by an inducing agent used experimentally to assess the level of temperate phage infection in the host population. On the other hand viral DNA might also have a protective role on the host (Baley et al. 2004). An example is provided by the discovery of a cyanophage encoding polypeptide D1 and D2 of the PSII, inducing repair cycles after photo-damage (Baley et al. 2004). Nevertheless it is not known at which extent the phage modifies the properties of PSII and therefore manipulates the photosynthetic physiology of the infected cells.

\section{CONCLUDING REMARKS}

Important advances in our perception of the significance of picocyanobacteria in freshwaters and oceans have occurred only within the last few decades, and these findings have come largely from an improved understanding of phylogenetic evolution of this major group. We now know that evolution of earliest cyanobacterial lineages were not marine, but likely were of terrestrial or freshwater origin and were unicellular.

The form-genus Synechococcus likely represents the ancestral morphology from which other types, including colonial forms, evolved. To what extent the formation of microcolonies is due to the presence of specific Synechococcus genotypes or is the result of survival strategy is presently not fully understood. The current challenge is to better understand the relationship between the diversity and ecology of Pcy and microcolonies and their interaction with the environmental factors that allow the proliferation of the most competitive genotypes.

\section{ACKNOWLEDGEMENTS}

I wish to thank the collaborative efforts of colleagues of the Microbial Ecology group of CNR-ISE Verbania, Italy.

\section{REFERENCES}

Adams, D.G. 2000. Symbiotic interactions. In: B.Whitton \& M. Potts (Eds), The ecology of cyanobacteria: their diversity in time and space. Kluwer Academic Publishers, Dordrecht: 523-561.

Ahlgren, N.A. \& G. Rocap. 2006. Culture isolation and culture-independent clone libraries reveal new marine Synechococcus ecotypes with distinctive light and N physiologies. Appl. Environ. Microbiol., 72: 7193-7204.

Ahlgren, N.A., G. Rocap \& W. Chisholm. 2006. Measurement of Prochlorococcus ecotypes using real-time polymerase chain reaction reveals different abundances of genotypes with similar light physiologies. Environ. Microbiol., 8: 441-454.

Allende, L. \& I. Izaguirre. 2003. The role of physical stability on the establishment of steady states in the phytoplankton community of two Maritime Antarctic lakes. Hydrobiologia, 502: 211-224.

Arndt, H. 1993. Rotifers as predators on components of the microbial web (bacteria, heterotrophic flagellates, ciliates) - a review. Hydrobiologia, 255/256: 231-246.

Beardall, J. \& J.A. Raven. 2004. Potential effects of global change on microalgal photosynthesis, growth and ecology. Phycologia, 43: 26-40.

Bec, A., D. Martin-Creuzburg \& E. von Elert. 2006. Trophic upgrading of autotrophic picoplankton by the heterotrophic nanoflagellate Paraphysomonas sp. Limnol. Oceanogr., 51: 1699-1707.

Becker, S., P. Richl \& A. Ernst. 2007. Seasonal and habitat related distribution pattern of Synechococcus genotypes in Lake Constance. FEMS Microbiol. Ecol., 62: 64-6.7

Becker, S., P. Böger, R. Oehlmann. \& A. Ernst. 2000. PCR bias in ecological analysis: a case study for quantitative Taq nuclease assays in analyses of microbial communities. Appl. Environ. Microbiol., 66: 4945-4953.

Becker, S., M. Fahrbach, P. Böger \& A. Ernst. 2002. Quantitative tracing, by Taq nuclease assays, of a Synechococcus ecotype in a highly diversified natural population. Appl. Environ. Microbiol., 68: 4486-4494.

Becker, S., A.K. Singh, C. Postius, P. Böger \& A. Ernst. 2004. Genetic diversity and distribution of periphytic Synechococcus spp. in biofilms and picoplankton of Lake Constance. FEMS Microbiol. Ecol., 49: 181-190.

Bell, T. \& L. Kalff. 2001. The contribution of picophytoplankton in marine and freshwater systems of different trophic status and depth. Limnol. Oceanogr., 46: 12431248.

Belykh, O.I., G. Ekaterina, T. Sorokovikova, A. Saphonova \& V. Tikhonova. 2006. Autotrophic picoplankton of Lake Baikal: composition, abundance and structure. Hydrobiologia, 568: 9-17. 
Berman, T., Y.Z. Yacobi \& U. Pollingher. 1992. Lake Kinneret phytoplankton: stability and variability during twenty years (1970-1989). Aquat. Sci., 54: 104-127.

Bertoni, R., R. Piscia \& C. Callieri. 2004. Horizontal heterogeneity of seston, organic carbon and picoplankton in the photic zone of Lago Maggiore, Northern Italy. J. Limnol., 63: 244-249.

Bird, C. \& M. Wyman. 2003. Nitrate/nitrite assimilation system od the marine picoplanktonic cyanobacterium Synechococcus sp. strain WH8103: effect of nitrogen source and availability on gene expression. Appl. Environ. Microbiol., 69: 7009-7018.

Blank, C.E. \& P. Sánchez-Baracaldo. 2010. Timing of morphological and ecological innovations in the cyanobacteria- a key to understanding the rise in atmospheric oxygen. Geobiology, 8: 1-23.

Boenigk, J., C. Matz, K. Jürgens \& H. Arndt. 2001. The influence of preculture conditions and food quality on the ingestion and digestion process of three species of heterotrophic nanoflagellates. Microb. Ecol., 42: 168-176.

Boersma, M. \& K. Wiltshire. 2006. Gut passage of phosphorus-limited algae through Daphnia: do they take up nutrients in the process? Arch. Hydrobiol., 167: 498-500.

Buma, A.G.J., E.J. van Hannen, M.J.W. Veldhuis \& W.W.C. Gieskes. 1995. Monitoring ultraviolet B-induced DNA damage in individual diatom cells by immuno-fluorescent thymin dimer detection. J. Phycol., 31: 314-321.

Burns, C.W. \& M. Schallenberg. 1996. Relative impacts of copepods, cladocerans and nutrients on the microbial food web of a mesotrophic lake. J. Plankton Res., 18: 683-714.

Burns, C.W. \& M. Schallenberg. 2001. Short-term impacts of nutrients, Daphnia, and copepods on microbial food-webs on an oligotrophic and eutrophic lake. New Zealand J. Mar. Freshwater Res., 35: 695-710.

Callieri, C. 1996. Extinction coefficient of red, green and blue light and its influence on Pcy types in lakes at different trophic levels. Mem. Ist. ital. Idrobiol., 54: 135-142.

Callieri, C. 2008. Picophytoplankton in freshwater ecosystems: the importance of small-sized phototrophs. Freshwat. Rev., 1: $1-28$.

Callieri, C. \& M.L. Pinolini. 1995. Picoplankton in Lake Maggiore, Italy. Int. Rev. ges. Hydrobiol., 80: 491-501.

Callieri, C. \& R. Piscia. 2002. Photosynthetic efficiency and seasonality of autotrophic picoplankton in Lago Maggiore after its recovery. Freshwat. Biol., 47: 941-956.

Callieri, C. \& J.G. Stockner. 2002. Freshwater autotrophic picoplankton: a review. J. Limnol., 61: 1-14.

Callieri, C., S.M. Karjalainen \& S. Passoni. 2002. Grazing by ciliates and heterotrophic nanoflagellates on picocyanobacteria in Lago Maggiore, Italy. J. Plankton Res., 24: 785-796.

Callieri, C., E. Amicucci, R. Bertoni \& L. Vörös. 1996. Fluorometric characterization of two picocyanobacteria strains from different underwater light quality. Int. Rev. ges. Hydrobiol., 81: 13-23.

Callieri, C., E. Balseiro, R. Bertoni \& B. Modenutti. 2004. Picocyanobacterial photosynthetic efficiency under Daphnia grazing pressure. J. Plankton Res., 26: 1471-1477.

Callieri, C., R. Bertoni, E. Amicucci, M.L. Pinolini \& I. Jasser. 1996. Growth rates of freshwater picocyanobacteria measured by FDC: problems and potentials for the estimation of picoplankton organic carbon synthesis. Arch. Hydrobiol. Spec. Issues Advanc. Limnol., 48: 93-103.

Callieri, C., E. Caravati, G. Morabito \& A. Oggioni. 2006. The unicellular freshwater cyanobacterium Synechococcus and mixotrophic flagellates: evidence for a functional association in an oligotrophic, subalpine lake. Freshwat. Biol., 51: 263-273.

Callieri, C., B. Modenutti, C. Queimaliños, R. Bertoni \& E. Balseiro. 2007. Production and biomass of picophytoplankton and larger autotrophs in Andean ultraoligotrophic lakes: differences in light harvesting efficiency in deep layers. Aquat. Ecol., 80: 345-362.

Callieri, C., G. Morabito, Y. Huot, P. Neal \& E. Lichman. 2001. Photosynthetic response of pico- and nanoplanktonic algae to UVB, UVA and PAR in a high mountain lake. Aquat. Sci., 63: 286-293.

Callieri, C., S. Moro, E. Caravati, N.D. Crosbie \& T. Weisse. 2005. Strain specific photosynthetic response of freshwater picocyanobacteria. Verh. Internat. Ver. Limnol., 29: 777-782.

Callieri, C. \& R. Bertoni. (2010). UVR and PAR effects on microcolony formation in Synechococcus: (in preparation).

Camacho, A., A. Picazo, M.R. Miracle \& E. Vicente. 2003. Spatial distribution and temporal dynamics of picocyanobacteria in a meromictic karstic lake. Algol. Studies, 109: $171-184$.

Caravati, E. 2008. Biodiversità e caratteristiche eco-fisiologiche dei picocianobatteri d'acqua dolce. $\mathrm{PhD}$ Thesis University of Parma: $133 \mathrm{pp}$.

Caravati, E., C. Callieri, B. Modenutti, G. Corno, E. Balseiro, R. Bertoni \& L. Michaud. 2010. Picocyanobacterial assemblages in ultraoligotrophic Andean lakes reveal high regional microdiversity. J. Plankton Res., 32: 357-366.

Carpenter, E.J. \& R.A. Foster. 2002. Marine symbioses. In: Rai, A.N., B. Bergman \& U. Rasmussen (Eds), Cyanobacteria in symbiosis. Kluwer Academic Publishers, The Netherlands: 11-8.

Carreto, J.I., M.O. Carignan, G. Daleo \& S.G. De Marco. 1990. Occurrence of mycosporine-like amino acids in the red tide dinoflagellate Alexandrium escavatum: UV-photoprotective compounds? J. Plankton Res., 12: 909-921.

Chen, F., K. Wang, J.J. Kan, M.T. Suzuki \& K.E. Wommack. 2006. Diverse and unique Pcy in Chesapeake Bay, revealed by $16 \mathrm{~S}-23 \mathrm{~S}$ rRNA internal transcribed spacer sequences. Appl. Environ. Microbiol., 72: 2239-2243.

Christoffersen, K. 1994. Variation of feeding activities of heterotrophic nanoflagellates on picoplankton. Mar. Microb. Food Webs, 8: 111-123.

Collos, Y., B. Bec, C. Jauzein, E. Abadie, T. Laugier, J. Lautier, A. Pastoureaud, P. Souchu \& A. Vaquer. 2009. Oligotrophication and emergence of picocyanobacteria and a toxic dinoflagellate in Thau lagoon, southern France. J. Sea Res., 61: 68-75.

Crosbie, N.D., M. Pöckl \& T. Weisse. 2003a. Dispersal and phylogenetic diversity of nonmarine picocyanobacteria, inferred from 16S rRNA gene and cpcBA-intergenic spacer sequence analyses. Appl. Environ. Microbiol., 69: 5716-5721.

Crosbie, N.D., M. Pöckl \& T. Weisse. 2003b. Rapid establishment of clonal isolates of freshwater autotrophic picoplankton by single-cell and single-colony sorting. J. Microbiol. Met., 55: 361-370.

Crosbie, N.D., K. Teubner \& T. Weisse. 2003c. Flow-cytometric mapping provides novel insights into the seasonal and vertical distributions of freshwater autotrophic picoplankton. Aquat. Microb. Ecol., 33: 53-66.

Dillon, A. \& J.D. Parry. 2008. Characterization of temperate cyanophages active against freshwater phycocyanin-rich Synechococcus spp. Freshwat. Biol., 53: 1253-1261.

Dillon, A. \& J.D. Parry. 2009. Amoebic grazing of freshwater Synechococcus strains rich in phycocyanin. FEMS Microbiol. Ecol., 69: 106-112.

Dillon, J.G., C.M. Tatsumi, P.G. Tandingan \& R.W. Castenholz. 2002. Effect of environmental factors on the synthesis of scytonemin, a UV-screening pigment, in a cyanobacterium (Chroococcidiopsis sp.). Arch. Microbiol., 177: 322-331.

Doolittle, W.F. 1999. Phylogenetic classification and the universal tree. Science, 284: 2124-2129.

Drakare, S., P. Blomqvist, A.K. Bergström \& M. Jansson. 2003. Relationships between picophytoplankton and envi- 
ronmental variables in lakes along a gradient of water colour and nutrient content. Freshwat. Biol., 48: 729740.

Dufresne, A., M. Ostrowski, D. Scanlan, L. Garczarek, S. Mazard, B.P. Palenik, I.T. Paulsen, N. Tandeau de Marsac, P. Wincker, C. Dossat, S. Ferriera, J. Johnson, A.P. Post, W.R. Hess \& F. Partensky. 2008. Unraveling the genomic mosaic of a ubiquitous genus of marine cyanobacteria. Genome Biol., 9(5): R90 (doi:10.1186/gb-2008-9-5r90).

DuRand, M.D., R.J. Olson \& S.W. Chisholm. 2001. Phytoplankton population dynamics at the Bermuda Atlantic Time-series station in the Sargasso Sea. Deep Sea Res., Part II 48: 1983-2003.

Ehling-Schulz, M., W. Bilger \& S. Scherer. 1997. UV-B-induced synthesis of photoprotective pigments and extracellular polysaccharides in the terrestrial cyanobacterium Nostoc commune. J. Bacterial, 179: 1940-1945.

Ernst, A. 1991. Cyanobacterial picoplankton from Lake Constance I. Isolation by fluorescence characteristics. $J$. Plankton Res., 13: 1307-1312.

Ernst, A., C. Postius \& P. Böger. 1996. Glycosylated surface proteins reflect genetic diversity among Synechococcus spp. of Lake Constance. Arch. Hydrobiol., 48: 1-6.

Ernst, A., S. Becker, K. Hennes \& C. Postius. 1999. Is there a succession in the autotrophic picoplankton of temperate zone lakes? In: Bell, C.R., M. Brylinski \& P. JohnsonGreen (Eds), Microbial biosystems: new frontiers. Proceedings of the 8th International Symposium on Microbial Ecology, Halifax, Canada: 623-629.

Ernst, A., S. Becker, V.I.A. Wollenzien \& C. Postius. 2003. Ecosystem dependent adaptive radiations of Picocyanobacteria inferred from 16S rRNA and ITS-1 sequence analysis. Microbiology, 149: 217-228.

Everroad, R.C. \& A.M. Wood. 2006. Comparative molecular evolution of newly discovered picocyanobacterial strains reveals a phylogenetically informative variable region of beta-phycoerythrin. J. Phycol., 42: 1300-1311.

Foster, R.A., J.L. Collier \& E.J. Carpenter. 2006. Reverse transcription PCR amplification of cyanobacterial symbiont 16S rRNA sequences from single non-photosynthetic eukaryotic marine planktonic host cells. J. Phycol., 42: 243-250.

Fu, F.X., M.E. Warner, Y. Zhang, Y. Feng \& D.A. Hutchins. 2007. Effects of increased temperature and $\mathrm{CO}_{2}$ on photosynthesis, growth, and elemental ratios in marine Synechococcus and Prochlorococcus (Cyanobacteria). J. Phycol., 43: 485-496.

Fuller, N.J., G.A. Tarran, M. Yallop, K.M. Orcutt \& D.J. Scanlan. 2006. Molecular analysys of picocyanobacterial community structure along an Arabian sea transect reveals distinct spatial separation of lineages. Limnol. Oceanogr., 51: 2515-2526.

Gaedke, U. \& T. Weisse. 1998. Seasonal and interannual variability of picocyanobacteria in Lake Costance. Arch. Hydrobiol. Spec. Issues Advanc. Limnol., 53: 143-158.

Garcia-Pichel, F. 1994. A model for internal self-shading in planktonic organisms and its implications for the usefulness of ultraviolet sunscreens. Limnol. Oceanogr., 39: 1704-1717.

Garcia-Pichel, F. \& R.W. Castenholz. 1991. Characterization and biological implications of scytonemin, a cyanobacteria sheath pigment. J. Phycol., 27: 395-409.

Garcia-Pichel, F. \& R.W. Castenholz. 1993. Occurrence of UV-absorbing, mycosporine-like compounds among cyanobacterial isolates and an estimate of their screening capacity. Appl. Environ. Microbiol., 59: 163-169.

Gervais, F., J. Padisák \& R. Koschel. 1997. Do light quality and low nutrient concentration favour picocyanobacteria below the thermocline of the oligotrophic Lake Stechlin? J. Plankton Res., 19: 771- 781.
Gismervik, I. 2006. Top-down impact by copepods on ciliate numbers and persistence depends on copepod and ciliate species composition. J. Plankton Res., 28: 499-507.

Glibert, P.M. \& R.T. Ray. 1990. Different patterns of growth and nitrogen uptake in two clones of marine Synechococcus spp. Mar. Biol., 107: 273-280.

Glover, H.E., D.A. Phinney \& C.S. Yentsch. 1985. Photosynthetic characteristics of picoplankton compared with those of larger phytoplankton populations in various water masses in the Gulf of Maine. Biol. Oceanogr., 3: 223-248.

Gophen, M. \& W. Geller. 1984. Filter mesh size and food particle uptake by Daphnia. Oecologia, 64: 408-412.

Gouvea, A.P., G.L. Boyer \& M.R. Twiss. 2008. Influeance of ultraviolet radiation, copper, and zinc on microcystin content in Microcystis aeruginosa (Cyanobacteria). Harmful Algae, 7: 194-205.

Grossman, A.R., M.R. Schaefer, G.G. Chiang \& J.L. Collier. 1993. The phycobilisome, a light-harvesting complex responsive to environmental conditions. Microbiol. Rev., 57: 725-749.

Harrison, J.W. \& R.E.H. Smith. 2009. Effects of ultraviolet radiation on the productivity and composition of freshwater phytoplankton communities. Photochem. Photobiol. Sci., 8: 1218-1232.

Hauschild, C.A., H.J.G. McMurter \& F.R. Pick. 1991. Effect of spectral quality on growth and pigmentation of picocyanobacteria. J. Phycol., 27: 698-702.

Haverkamp, T., S.G. Acinas, M. Doeleman, M. Stomp, J. Huisman \& L.J. Stal. 2008. Diversity and phylogeny of Baltic Sea picocyanobacteria inferred from their ITS and phycobiliprotein operons. Environ. Microbiol., 10: 174188.

Haverkamp, T.H.A., D. Schouten, M. Doeleman, U. Wollenzien, J. Huisman \& L.J. Stal. 2009. Colorful microdiversity of Synechococcus strains (picocyanobacteria) isolated from the Baltic Sea. ISME J., 3: 397-408.

Hawley, G.R.W. \& B.A. Whitton. 1991. Seasonal changes in chlorophyll-containing piocplankton populations of ten lakes in Northern England. Int. Rev. ges. Hydrobiol., 76: 545-554.

Helbling, E.W., V.E. Villafañe \& E.S. Barbieri. 2001. Sensitivity of winter phytoplankton communities from Andean lakes to artificial ultraviolet-B radiation. Rev. Chil. Hist. Nat., 74: 273-282.

Helbling, E.W., M.E. Farías, M.V. Fernández Zenoff \& V.E. Villafañe. 2006. In situ responses of phytoplankton from the subtropical Lake La Angostura (Tucumán, Argentina) in relation to solar ultraviolet radiation exposure and mixing conditions. Hydrobiologia, 559: 123-134.

Honda, D., A. Yokota \& J. Sugiyama. 1999. Detection of seven major evolutionary lineages in cyanobacteria based on the 16S rRNA gene sequence analysis with new sequences of five marine Synechococcus strains. J. Mol. Evol., 48: 723-739.

Hopkinson, B.M. \& F.M.M. Morel. 2009. The role of siderophores in iron acquisition by photosynthetic marine microorganisms. Biometals, 22: 656-669.

Ilikchyan, I.N., R.M.L. McKay, J.P. Zehr, S.T. Dyhrman \& G.S. Bullerjahn. 2009. Detection and expression of the phosphonate transporter gene PHND in marine and freshwater Picocyanobacteria. Environ. Microbiol., 11: 13141324.

Iturriaga, R. \& B.G. Mitchell. 1986. Chroococcoid cyanobacteria: a significant component in the food web dynamics of the open ocean. Mar. Ecol. Prog. Ser., 28: 291-297.

Ivanikova, N.V., L.C. Popels, R.M.L. McKay \& G.S. Bullerjahn. 2007. Lake Superior supports novel clusters of cyanobacterial picoplankton. Appl. Environ. Microbiol., 73: 4055-4065.

Izaguirre, I., L. Allende \& M.C. Marinone. 2003. Comparative study of the planktonic communities of three lakes of 
contrasting trophic status at Hope Bay (Antarctic Peninsula). J. Plankton Res., 25: 1079-1097.

Jacquet, S., I. Domaizon, S. Personnic \& T. Sime-Ngando. 2007. Do small grazers influence viral-induced bacterial mortality in Lake Bourget? Fund. Appl. Limnol., 170: 125-132.

Jansson, M., H. Olsson \& K. Pettersson. 1988. Phosphatases: origin, characteristic and function in lakes. Hydrobiologia, 170: $157-175$

Jasser, I. 1997. The dynamics and importance of picoplankton in shallow, dystrophic lake in comparison with surface waters of two deep lakes with contrasting trophic status. Hydrobiologia, 342/343: 87-93.

Jasser, I. \& L. Arvola. 2003. Potential effects of abiotic factors on the abundance of autotrophic picoplankton in four boreal lakes. J. Plankton Res., 25: 873-883.

Jezberová, J. \& J. Komárková. 2007. Morphological transformation in a freshwater Cyanobium sp. induced by grazers. Environ. Microbiol., 9: 1858-1862.

Jochem, F.J. 2000. Probing the physiological state of phytoplankton at the single-cell level. Sci. Mar., 64: 183-195.

Kana, T.M. \& P.M. Glibert. 1987. Effect of irradiances up to $2000 \mu \mathrm{E} \mathrm{m}^{-2} \mathrm{~s}^{-1}$ on marine Synechococcus WH7803 -II. Photosynthetic responses and mechanisms. Deep Sea Res., 34: 497-516.

Karentz, D., F.S. McEuen, M.C. Land W.C. Dunlap. 1991. Survey of mycosporine-like amino acid compounds in antarctic marine organisms: potential protection from ultraviolet exposure. Mar. Biol., 108: 157-166.

Kasai, F., M.J. Waiser, R.D. Robarts \& M.T. Arts. 2001. Size dependent UVR sensitivity in Redberry lake phytoplankton communities. Ver. Internat. Verein. Limnol., 27: 20182023.

Kasprzak, P., F. Gervais, R. Adrian, W. Weiler, R. Radke, I. Jaeger, S. Riest, U. Siedel, V. Schneider, M. Boehme, R. Eckmann \& N. Walz. 2000. Trophic characterization, pelagic food web structure and comparison of two mesotrophic lakes in Brandenburg (Germany). Int. Rev. ges. Hydrobiol., 85: 167-189.

Katano, T., S. Nakano, H. Ueno, U. Mitamura, K. Anbutsu, M. Kihira, Y. Satoh, V. Drucker \& M. Sugiyama. 2005. Abundance, growth and grazing loss rates of picophytoplankton in Barguzin Bay, Lake Baikal. Aquat. Ecol., 39: 431-438.

Katano, T., S. Nakano, O. Mitamura, H. Yoshida, H. Azumi, Y. Matsuura, Y. Tanaka, H. Maezono, Y. Satoh, T. Satoh, Y. Sugiyama, Y. Watanabe, T. Mimura, Y. Akagashi, H. Machida, V. Drucker, I. Tikhonova, O. Belykh, V.A. Fialkov, M.S. Han, S.H. Kang \& M. Sugiyama. 2008. Abundance and pigment type composition of picocyanobacteria in Barguzin Bay, Lake Baikal. Limnology, 9: 105-114.

Koblížek, M., J. Komenda, J. Masojídek \& L. Pechar. 2000. Cell aggregation of the cyanobacterium Synechococcus elongatus: role of the electron transport chain. J. Phycol., 36: 662-668

Komárek, J. 1996. Towards a combined approach for the taxonomic and species delimitation of picoplanktic cyanoprokaryotes. Algol. Studies, 83: 377-401.

Komárek, J. \& K. Anagnostidis. 1999. Cyanoprokaryota 1. Teil Chroococcales. Süsswasserflora von Mitteleuropa 19/1 Gustav Fischer, Jena, 548pp.

Komárek, J., V. Cepák, J. Kaštovský \& J. Sulek. 2004. What are the cyanobacterial genera Cyanothece and Cyanobacterium? Contribution to the combined molecular and phenotype taxonomic evaluation of cyanobacterial diversity. Algol. Studies, 113: 1-36.

Komárková, J. 2002. Cyanobacterial picoplankton and its colonial formations in two eutrophic canyon reservoirs (Czech Republic). Arch. Hydrobiol., 154: 605-623.

Laurion, I. \& W.F. Vincent. 1998. Cell size vs taxonomic composition as determinants of UV sensitivity in natural phytoplankton communities. Limnol. Oceanogr., 43: 1774-1779.

Lavallée, B.F. \& F.R. Pick. 2002. Picocyanobacteria abundance in relation to growth and loss rates in oligotrophic to mesotrophic lakes. Aquat. Microb. Ecol., 27:3 7-46.

Li, W.K.W. 1998. Annual average abundance of heterotrophic bacteria and Synechococcus in surface ocean waters. Limnol. Oceanogr., 43: 1743-1753.

Liu, Z., D.P. Häder \& R. Sommaruga. 2004. Occurrence of mycocporine-like aminoacids (MAAs) in the bloomforming cyanobacterium Microcyctis aeruginosa. $J$. Plankton Res., 26: 963-966.

Liu, X., M. Shi, Y. Liao, Y. Gao, Z. Zhang, D. Wen, W. Wu \& C. An. 2006. Feeding characteristics of an amoeba (Lobosea: Naegleria) grazing upon cyanobacteria: food selection, ingestion and digestion process. Microb. Ecol., 51: $315-325$

Mackey, K.R.M., A. Paytan, A.R. Grossman \& S. Bailey. 2008. A photosynthetic strategy for coping in a high-light, low-nutrient environment. Limnol. Oceanogr., 53: 900913.

Mackey, K.R.M., T. Rivlin, A.R. Grossman, A.F. Post \& A. Paytan. 2009. Picophytoplankton responses to changing nutrient and light regimes during a bloom. Mar. Biol., 156: $1535-1546$

Maeda, H., A. Kawai \& M.M. Tilzer. 1992. The water bloom of cyanobacterial picoplankton in Lake Biwa, Japan. Hydrobiologia, 248: 93-103.

Mann, N.H. 2003. Phages of marine cyanobacterial picophytoplankton. FEMS Microbiol. Rev., 27: 17-34.

Martin-Creuzburg, D. \& E. Von Elert. 2006. Trophic upgrading of autotrophic picoplankton by the heterotrophic nanoflagellate Paraphysomonas sp. Limnol. Oceanogr., 51: 1699-1707.

Massana, R., J. del Campo, C. Dinter \& R. Sommaruga. 2007. Crash of a population of the marine heterotrophic flagellate Cafeteria roenbergensis by viral infection. Environ. Microbiol., 9: 2660-2669.

Mills, M.M., C. Ridame, M. Davey \& J. La Roche. 2004. Iron and phosphorus co-limit nitrogen fixation in the eastern tropical North Atlantic. Nature, 429: 292-294.

Modenutti, B.E. \& E.G. Balseiro. 2002. Mixotrophic ciliates in an Andean lake: dependence on light and prey of an Ophrydium naumanni population. Freshwat. Biol., 47: 121-128.

Morel, A. \& A. Bricaud. 1981. Theoretical results concerning light absorption in a discrete medium, an application to specific absorption of phytoplankton. Deep-Sea Res., 28: $1375-1393$

Morris, I. \& H.E. Glover. 1981. Physiology of photosynthesis by marine coccoid cyanobacteria some ecological implications. Limnol. Oceanogr., 26: 957-961.

Moser, M., C. Callieri \& T. Weisse. 2009. Photosynthetic and growth response of freshwater picocyanobacteria are strain-specific and sensitive to photoacclimation. $J$. Plankton Res., 31: 349-357.

Moutin, T., T.R. Thingstad, F. Van Wambeke, D. Marie, G. Slawyk, P. Raimbault \& H. Claustre. 2002. Does competition for nanomolar phosphate supply explain the predominance of the cyanobacterium Synechococcus? Limnol. Oceanogr., 47: 1562-1567.

Mózes, A., M. Présing \& L. Vörös. 2006. Seasonal dynamics of picocyanobacteria and picoeukaryotes in a large shallow lake (Lake Balaton, Hungary). Internat. Rev. ges. Hydrobiol., 91: 38-50.

Muhling, M., N.J. Fuller, A. Millard, P.J. Somerfield, D. Marie, W.H. Wilson, D.J. Scanlan, A.F. Post, I. Joint \& N.H. Mann. 2005. Genetic diversity of marine Synechococcus and co-occurring cyanophage community: evidence for viral control of phytoplankton. Environ. Microbiol., 7: 499-508. 
Murphy, T.P., D.R.S. Lean \& C. Nalewajko. 1976. Blue-green algae:their excretion of iron-selective chelators enables them to dominate other algae. Science, 192: 900-902.

Nagata, T., K. Takai, K. Kawanobe, D. Kim, R. Nakazato, N. Guselnikova, N. Bondarenko, O. Mologawaya, T. Kostrnova, V. Drucker, Y. Satoh \& Y. Watanabe. 1994. Autotrophic picoplankton in southern Lake Baikal: abundance growth and grazing mortality during summer. J. Plankton Res., 16: 945-959.

Nedoma, J., A. Štrojsová, J. Vrba, J. Komárková \& K. Šimek. 2003. Extracellular phosphatase activity of natural plankton studied with ELF97 phosphate: fluorescence quantification and labelling kinetics. Environ. Microbiol., 5: 462472.

Padisák, J., F.A.R. Barbosa, R. Koschel \& L. Krienitz. 2003. Deep layer cyanoprokaryota maxima are constitutional features of lakes: examples from temperate and tropical regions. Arch. Hydrobiol. Special Issue Adv. Limnol., 58: 175-199.

Padisák, J., L. Krienitz, R. Koschel \& J. Nedoma. 1997. Deeplayer autotrophic picoplankton maximum in the oligotrophic Lake Stechlin, Germany: origin, activity, development and erosion. Eur. J. Phycol., 32: 403-416.

Padisák, J., L. Krienitz, W. Scheffler, R. Koschel, J. Kristiansen \& I. Grigorszky. 1998. Phytoplankton succession in the oligotrophic Lake Stechlin (Germany) in 1994 and 1995. Hydrobiologia, 369/370: 179-197.

Palenik, B., B. Brahamsha, F.W. Larimer, M. Land, L. Hauser, P. Chain, J. Lamerdin, W. Regala, E.E. Allen, J. McCarren, I. Paulsen, A. Dufresne, F. Partensky, E.A. Webb \& J. Waterbury. 2003. The genome of a motile marine Synechococcus. Nature, 424: 1037-1042.

Passoni, S. \& C. Callieri. 2000. Picocyanobacteria single forms, aggregates and microcolonies: survival strategy or species succession? Ver. Internat. Verein Limnol., 27: 1879-1883.

Pérez, G., C. Quemaliños \& B. Modenutti. 2002. Light climate and plankton in the deep chlorophyll maxima in North Patagonian Andean lakes. J. Plankton Res., 24: 591-599.

Pernthaler, J., K. Šimek, B. Sattler, A. Schwarzenbacher, J. Bobkova \& R. Psenner. 1996. Short-term changes of protozoan control on autotrophic picoplankton in an oligomesotrophic lake. J. Plankton Res., 18: 443-462.

Personnic, S., I. Domaizon, T. Sime-Ngando \& S. Jacquet. $2009 \mathrm{~b}$. Seasonal variations of microbial abundances and virus-versus flagelate-induced mortality of picoplankton in three peri-alpine lakes. J. Plankton Res., 31: 1161-1177.

Personnic, S., I. Domaizon, U. Dorigo, L. Berdjeb \& S. Jacquet. 2009a. Seasonal and spatial variability of virio-, bacterio-, and picophytoplanktonic abundances in three peri-alpine lakes. Hydrobiologia, 627: 99-116.

Peštová, D., M. Macek \& M.E. Martínez Pérez. 2008. Ciliates and their picophytoplankton-feeding activity in a high-altitude warm-monomictic saline lake. Eur. J. Prot., 44: 13-25.

Pick, F.R. 1991. The abundance and composition of freshwater picocyanobacteria in relation to light penetration. Limnol. Oceanogr., 36: 1457-1462.

Pick, F.R. \& D.M. Agbeti. 1991. The seasonal dynamic and composition of photosynthetic picoplankton communities in temperate lakes in Ontario, Canada. Int. Rev. ges. Hydrobiol., 76: 565-580.

Ploug, H., W. Stolte \& B.B. Jørgensen. 1999. Diffusive boundary layers of the colony-forming plankton alga Phaeocystis sp. - implications for nutrient uptake and cellular growth. Limnol. Oceanogr., 44: 1959-1967.

Porter, K.G. 1973. Selective grazing and differential digestion of algae by zooplankton. Nature, 244: 179-180.

Porter, K.G. 1975. Viable gut passage of gelatinous green algae ingested by Daphnia. Ver. Internat. Verein. Limnol., 19: 2840-2850.
Postius, C. \& P. Böger. 1998. Differentinteractions of phycoerythrin- and phycocyanin-rich Synechococcus spp. with diazotrophic bacteria from the picoplankton of Lake Constance. Arch. Hydrobiol., 141: 181-194.

Postius, C. \& A. Ernst. 1999. Mechanisms of dominance: coexistence of picocyanobacterial genotypes in a freshwater ecosystem. Arch. Microbiol., 172: 69-75.

Powell, L.M., J.P. Bowman, J.H. Skerratt, P.D. Franzmann \& H.R. Burton. 2005. Ecology of a novel Synechococcus clade occurring in dense populations in saline Antarctic lakes. Mar. Ecol. Prog. Ser., 291: 65-80.

Reynolds, C.S., V. Huszar, C. Kruk, L. Naselli-Flores \& S. Melo. 2002. Towards a functional classification of the freshwater phytoplankton. J. Plankton Res., 24: 417-428.

Robertson, B.R., N. Tezuka \& M.M. Watanabe. 2001. Phylogenetic analyses of Synechococcus strains (Cyanobacteria) using sequences of $16 \mathrm{~S}$ rDNA and part of the phycocyanin operon reveal multiple evolutionary lines and reflect phycobilin content. Internat. J. Syst. Evol. Microbiol., 51: 861-871.

Rocap, G., D.L. Distel, J.B. Waterbury \& S.W. Chisholm. 2002. Resolution of Prochlorococcus and Synechococcus ecotypes by using $16 \mathrm{~S}-23 \mathrm{~S}$ ribosomal DNA internal transcribed spacer sequences. Appl. Environ. Microbiol., 68: 1180-1191.

Ronneberger, D. 1998. Uptake of latex beads as size-model for food of planktonic rotifers. Hydrobiologia, 387/388, 445-449.

Sánchez-Baracaldo, P., B.A. Handley \& P.K. Hayes. 2008. Picocyanobacterial community structure of freshwater lakes and the Baltic Sea revealed by phylogenetic analyses and clade-specific quantitative PCR. Microbiology, 154: 33473357.

Sánchez-Baracaldo, P., P.K. Hayes \& C.E. Blank. 2005. Morphological and habitat evolution in the cyanobacteria using a compartmentalization approach. Geobiology, 3: 145165.

Sanders, R.W., U.G. Berninger, E.L. Lim, P.F. Kemp \& D.A. Caron. 2000. Heterotrophic and mixotrophic nanoplankton predation on picoplankton in the Sargasso Sea and Georges Bank. Mar. Ecol. Prog. Ser., 192: 103-118.

Scanlan, D.J. \& N.J. West. 2002. Molecular ecology of the marine cyanobacterial genera Prochlorococcus and Synechococcus. FEMS Microbiol. Ecol., 40: 1-12.

Scanlan, D.J., M. Ostrowski, S. Mazard, A. Dufresne, L. Garczarek, W. R. Hess, A.F. Post, M. Hagemann, I. Paulsen \& R. Partensky. 2009. Ecological genomics of marine picocyanobacteria. Microbiol. Mol. Biol. Rev., 73: 249-299.

Shannon, S., T. Chrzanowski \& J. Grover. 2007. Prey food quality affects flagellate ingestion rates. Microb. Ecol., 53: 66-73.

Šimek, K. \& T.H. Chrzanowski. 1992. Direct and indirect evidence of size-selective grazing on pelagic bacteria by freshwater nanoglagellates. Appl. Environ. Microbiol., 58: 3715-3720.

Šimek, K., J. Bobkova, M. Macek, J. Nedoma \& R. Psenner. 1995. Ciliate grazing on picoplankton in a eutrophic reservoir during the summer phytoplankton maximum: a study at the species and community level. Limnol. Oceanogr., 40: 1077-1090.

Sime-Ngando, T. 1995. Population dynamics of autotrophic picoplankton in relation to environmental factors in a productive lake. Aquat. Sci., 57: 91-105.

Sinha, R.P. \& D.P. Häder. 2008. UV-protectants in cyanobacteria. Plant Sci., 174: 278-289.

Six, C., J.C. Thomas, L. Garczarek, M. Ostrowski, A. Dufresne, N. Blot et al. 2007. Diversity and evolution of phycobilisomes in marine Synechococcus spp.: a comparative genomics study. Genome Biol., 8: R259. 
Sommaruga, R. 2009. Perspectives and research on environmental effects of ultraviolet radiation. Photochem. Photobiol. Sci., 8: 1217.

Sommaruga, R., Y. Chen Z. Liu. 2008. Multiple strategies of bloom-forming Microcyctis to minimaze damage by solar ultraviolet radiation in surface waters. Microb. Ecol., 57: 667-674.

Sommaruga, R., J.S. Hofer, L. Alonso-Sáez J.M. Gasol. 2005. Differential sunlight sensitivity of picophytoplankton from surface mediterranean coastal waters. Appl. Environ. Microbiol., 71: 2154-2157.

Søndergaard, M. 1991. Phototrophic picoplankton in temperate lakes: seasonal abundance and importance along a trophic gradient. Int. Rev. ges. Hydrobiol., 76: 505-522.

Stockner, J.G. 1991. Autotrophic picoplankton in freshwater ecosystems: the view from the summit. Int. Rev. ges. Hydrobiol., 76: 483-492.

Stockner, J.G. \& N.J. Antia. 1986. Algal picoplankton from marine and freshwater ecosystems: a multidisciplinary perspective. Can. J. Fish. Aquat. Sci., 43: 2472-2503.

Stockner, J.G. \& K.G. Porter. 1988. Microbial food webs in fresh-water planktonic ecosystems. In: S.R. Carpenter (Ed.), Complex interactions in lake communities. SpringerVerlag New York: 69-83.

Stockner, J.G. \& K.S. Shortreed. 1989. Algal picoplankton production and contribution to food webs in oligotrophic British Columbia lakes. Hydrobiologia, 173: 151-166.

Stockner, J.G. \& K.S. Shortreed. 1994. Autotrophic picoplankton community dynamics in a pre-alpine lake in British Columbia, Canada. Hydrobiologia, 274: 133-142.

Stockner, J., C. Callieri \& G. Cronberg. 2000. Picoplankton and other non-bloom forming cyanobacteria in lakes. In: B. Whitton \& M. Potts (Eds), The ecology of cyanobacteria: their diversity in time and space. Kluwer Academic Publishers, Dordrecht: 195-238.

Stomp, M., J. Huisman, L. Vörös, F.R. Pick, M. Laamanen, T. Haverkamp \& L.J. Stal. 2007. Colorful coexistence of red and green picocyanobacteria in lakes and seas. Ecol. Lett., 10: 290-298.

Stomp, M., J. Huisman, F. de Jongh, A.J. Veraart, D. Gerla, M. Rijkeboer, B.W. Ibelings, U.I.A. Wollenzien \& L.J. Stal. 2004. Adaptive divergence in pigment composition promotes phytoplankton biodiversity. Nature, 432: 104-107.

Straškrabová, V., C. Callieri \& J. Fott (Eds). 1999. Pelagic food web in mountain lakes (Mountain Lakes Research Program). J. Limnol., 58(2): 222 pp.

Štrojsová, A., J. Vrba, J. Nedoma, J. Komarková \& P. Znachor. 2003. Seasonal study of extracellular phosphatase expression in the phytoplankton of a eutrophic reservoir. Eur. J. Phycol., 38: 295-306.

Sundt-Hansen, L.E., Y. Olsen, H. Stibor, M. Heldal \& O. Vadstein. 2006. Trophic cascades mediated by copepods, not nutrient supply rate, determine the development of picocyanobacteria. Aquat. Microb. Ecol., 45: 207-218.

Suttle, C. 2000. Cyanophages and their role in the ecology of cyanobacteria. In: B. Whitton \& M. Potts (Eds), The ecology of cyanobacteria: their diversity in time and space. Kluwer Academic Publishers, Dordrecht: 563-589.

Szelag-Wasielewska, E. 2003. Phytoplankton community structure in non-stratified lakes of Pomerania (NW Poland). Hydrobiologia, 506-509: 229-236.

Takano, H., T. Arai, M. Hirano \& T. Matsunaga. 1995. Effects of intensity and quality of light on phycocyanin production by a marine cyanobacterium Synechococcus sp. NKBG 042902. Appl. Microbiol. Biotechnol., 43: 1014-1018.

Tarao, M., J. Jezbera M. Hahn. 2009. Involvement of cell surface structures in size-independent grazing resistance of freshwater Actinobacteria. Appl. Environ. Microbiol., 75: 4720-4726.
Taylor, G.T. 1982. The role of pelagic heterotrophic protozoa in nutrient cycling: a review. Ann. Inst. Oceanogr., 58: 227-241.

Timmermans, K.R., B. van der Wagt, M.J.W. Veldhuis, A. Maatman \& H.J.W. de Baar. 2005. Physiological responses of three species of marine pico-phytoplankton to ammonium, phosphate, iron and light limitation. J. Sea Res., 53: 109-120.

Toro, M., A. Camacho, C. Rochera, E. Rico, M. Bañón, E. Fernandez-Valiente, E. Marco, A. Justel, M.C. Avendañn, Y. Ariosa, W.F. Vincent \& A. Quesada. 2007. Limnological characteristics of freshwater ecosystems of byers peninsula, Livingstone Island, in maritime Antarctica. Polar Biol., 30: 635-649.

Urbach, E., D.J. Scanlan, D.L. Distel, J.B. Waterbury \& S.W. Chisholm. 1998. Rapid diversification of marine picophytoplankton with dissimilar light-harvesting structure inferred from sequences of Prochlorococcus and Synechococcus (Cyanobacteria). J. Mol. Evol., 46: 188-201.

Vadstein, O. 2000. Heterotrophic planktonic bacteria and cycling of phosphorus: phosphorus requirements, competitive ability, and food web interactions. In: B. Schink (Ed.), Advances in microbial ecology. Kluwer Academic Publisher, New York, 16: 115-167.

Van Donk, E. \& D.O. Hessen. 1993. Grazing resistance in nutrient-stressed phytoplankton. Oecologia, 93: 508-511.

Van Donk, E., B. A. Faafeng, H. J. De Lange \& D. O. Hessen. 2001. Differential sensitivity to natural ultraviolet radiation among phytoplankton species in Arctic lakes (Spitsbergen, Norway). Plant Ecol., 154: 247-259.

Van Mooy, B.A.S., G. Rocap, H.F. Fredericks, C.T. Evans \& A.H. Devol. 2006. Sulfolipids dramatically decrease phosphorus demand by picocyanobacteria in oligotrophic marine environments. Proc. Nat. Acad. Sci., 103: 8607-8612.

Vázquez-Domínguez, E., C.M. Duarte, S. Agustí, K. Jürgens, D. Vaqué \& J.M. Gasol. 2008. Microbial plankton abundance and heterotrophic activity across the Central Atlantic Ocean. Progress in Oceanogr., 79: 83-94.

Veldhuis, M.J.W. \& W. Admiral. 1987. Influence of phosphate depletion on the growth and colony formation of Phaeocystis pouchetii. Mar Biol., 95: 47-54.

Villafañe, V.E., M.A. Marcoval \& E.W. Helbling. 2004. Photosynthesis versus irradiance characteristics in phytoplankton assemblages off Patagonia (Argentina): temporal variability and solar UVR effects. Mar. Ecol. Prog. Ser., 284: 23-34.

Villafañe, V.E., K. Sundbäck, F.L. Figueroa \& E.W. Helbling. 2003. Photosynthesis in the aquatic environment as affected by UVR. In: E.W. Helbling \& H. Zagarese (Eds), UV effects in aquatic organisms and ecosystems. Compr. Ser. Photochem. Photobiol. Sci., The Royal Society of Chemistry, Cambridge: 357-398.

Villafañe, V.E., M. Andrade, V. Lairana, F. Zaratti \& E.W. Helbling. 1999. Inhibition of phytoplankton photosynthesis by solar ultraviolet radiation: studies in Lake Titicaca, Bolivia. Freshwat. Biol., 42: 215-224.

Vincent, W.F. 2000. Cyanobacteria dominance in the polar region. In: B. Whitton \& M. Potts (Eds), The ecology of cyanobacteria: their diversity in time and space. Kluwer Academic Publishers, Dordrecht: 321-340.

Vincent, W.F., J.P. Bowman, L.M. Rankin \& T.A. McMeekin. 2000. Phylogenetic diversity of picocyanobacteria in Arctic and Antarctic ecosystems. In: C.R. Bell, M. Brylinsky \& P. Johnson-Green (Eds), Microbial biosystems: new frontiers. Atlantic Canada Society for Microbial Ecology, Halifax, Canada: 317-322.

Vörös, L., A. Mózes \& B. Somogyi. 2009. A five-year study of autotrophic winter picoplankton in Lake Balaton, Hungary. Aquat. Ecol., 43: 727-734. 
Vörös, L., C. Callieri, K.V. Balogh \& R. Bertoni. 1998. Freshwater picocyanobacteria along trophic gradient and light quality range. Hydrobiologia, 369/370: 117-125.

Weinbauer, M.G. 2004. Ecology of prokaryotic viruses. FEMS Microbiol. Rev., 28: 127-181.

Weisse, T. 1993. Dynamics of autotrophic picoplankton in marine and freshwater ecosystems. In: J.G. Jones (Ed.), Advances in microbial ecology. Plenum Press, New York, 13: 327-370.

Weisse, T. \& U. Kenter. 1991. Ecological characteristics of autotrophic picoplankton in a prealpine lake. Int. Rev.ges. Hydrobiol., 76: 493-504.

Weisse, T. A. Schweizer. 1991. Seasonal and interannual variation of autotrophic picoplankton in a large prealpine lake (Lake Constance). Verh. Internat. Verein. Limnol., 24: 821-825.

Wilhelm, S.W. 1995. Ecology of iron-limited cyanobacteria: a review of physiological responses and implications for aquatic systems. Aquat. Microb. Ecol., 9: 295-303.

Winder, M. 2009. Photosynthetic picoplankton dynamics in Lake Tahoe: temporal and spatial niche partitioning among prokaryotic and eukaryotic cells. J. Plankton Res., 31: 1307-1320.

Wood, A.M. \& L.M. Van Valen. 1990. Paradox lost? On the release of energy-rich compounds by phytoplankton. Mar. Microb. Food Webs, 4: 103-116.

Wood, A.M., P.K. Horan, K. Muirhead, D.A. Phinney, C.M. Yentsch \& J.B. Waterbury. 1985. Discrimination between types of pigments in marine Synechococcus spp. by scanning spectroscopy, epifluorescence microscopy and flow cytometry. Limnol. Oceanogr., 30: 1303-1315.

Received: February 2010

Accepted: May 2010
Yoshida, T., T.B. Gurung, M. Kagami \& J. Urabe. 2001. Contrasting effects of cladoceran (Daphnia galeata) and calanoid copepod (Eodiaptomus japonicus) on algal and microbial plankton in a Japanese lake, Lake Biwa. Oecologia, 129: 602-610.

Zeidner, G., J.P. Bielawski, M. Shmoish, D.J. Scanlan, G. Sabehi \& O. Beja. 2005. Potential photosynthesis gene recombination between Prochlorococcus and Synechococcus via viral intermediates. Environ. Microbiol., 7: 15051513.

Zöllner, E., B. Santer, M. Boersma, H.G. Hoppe \& K. Jürgens. 2003. Cascading predation effects of Daphnia and copepods on microbial food web components. Freshwat. Biol., 48: 2174-2193.

Zwirglmaier, K., J.L. Heywood, K. Chamberlain, E. Malcolm, S. Woodward, M.V. Zubkov \& D.J. Scanlan. 2007. Basinscale distribution patterns of picocyanobacterial lineages in the Atlantic Ocean. Environ. Microbiol., 9: 1278-1290.

Zwirglmaier, K., E. Spence, M.V. Zybkov, D.J. Scanlan \& N. Mann. 2009. Differential grazing of two heterotrophic nanoflagellates on marine Synechococcus strains. Environ. Microbiol., 11: 1767-1776.

Zwirglmaier, K., L. Jardillier, M. Ostrowski, S. Mazard, L. Garczarek, D. Vaulot, F. Not, R. Massana, O. Ulloa \& D.J. Scanlan. 2008. Global phylogeography of marine Synechococcus and Prochlorococcus reveals a distinct partitioning of lineages among oceanic biomes. Environ. Microbiol., 10:147-161. 